Journal of Research and Review in Science, 30-50

Volume 5, December 2018

DOI10.36108/jrrslasu/8102/50(0150)

ORIGINAL RESEARCH

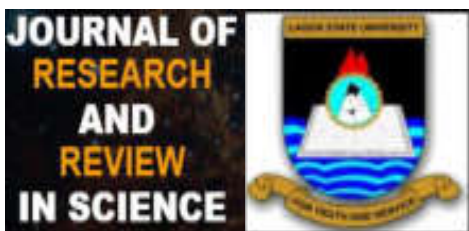

\title{
Ethno-botanical survey, review and informatics of medicinal plants used by indigenous people of Lekki, Ibeju-Lekki Local Government Area of Lagos State, Nigeria.
}

Korede Taiwo ${ }^{1}$, Sunday Makinde ${ }^{2}$, Anthony Ojekale ${ }^{3}$, Margaret Sowunmi ${ }^{4}$, Opeyemi Oyetunji ${ }^{5}$ and Malik Lasisi ${ }^{6}$

${ }^{1,4}$ Department of Archaeology and Anthropology, University of Ibadan, Ibadan Oyo State Nigeria

${ }^{2,5}$ Department of Botany, Faculty of Science,

Lagos State University, Nigeria

${ }^{3,6}$ Department of Biochemistry, Faculty of Science,

Lagos State University, Nigeria

\section{Correspondence}

Anthony Babajide Ojekale, Department of Biochemistry, Faculty of Science, Lagos State University, Lagos, Nigeria.

Email:Anthony.ojekale@lasu.edu.ng

\begin{abstract}
:
The use of medicinal plants (herbal) is common among the rural populace in most countries, Nigeria inclusive.

Aims: This study focusses on a survey of ethnopharmacology of medicinal plants and preparations used to manage common ailments within the people of Lekki, Lagos, Nigeria.

Materials and Methods: Randomly selected respondents from two rural communities (Lekki Oke and Isale Lekki) were used for this study.

Results: The survey results returned 43 plants as being commonly used medicinal plants. About $28(44 \%)$ of these had scientific data backing their medicinal usage. Nutraceuticals account for about $37(58 \%)$ of the plants surveyed. About three quarters $(74 \%)$ of the surveyed plants have multiple uses. The leaves and roots (20\%) are the most commonly employed parts of the plant for medicinal treatment, while the stem and whole plant are the least used (2\%). Decoction (35\%), concoctions $(20 \%)$ and macerations $(17 \%)$ are the most common preparation modes of the plant extracts.

Conclusion Data analysis showed that with advancement in extraction, analytical and evaluation techniques, empirical data are confirming the efficacy of these herbs used by the locals. The culture and traditions of the Lekki people in the use of herbals for health management is further affirmed with this survey. The culture and traditions of the Lekki people in the use of herbals for health management is affirmed with this survey.
\end{abstract}

To Keywords: Ethno-botanical, survey, medicinal plants, herbals, Lekki Oke and Isale Lekki 


\section{INTRODUCTION}

Man since time immemorial had depended on the use of plants in his daily activities. Plants serve as food, building shelter components, herbs, fodder amongst other numerous uses. The use of plants as medicine is as old as time itself, and is a global phenomenon that cuts across level of development, faith, social or economic status [1-3]. In Africa, as high as $80 \%$ of the population depend on herbal medicines in one form or the other [4]. In Nigeria, a large section of the populace are still dependent on plants as medicines[5] as a result of lack of availability and cost of western medicare. The history, culture and traditions of a people also contribute to the reasons for usage of plants as medicines. The composition of the mixture of plant parts used in the treatment of various ailments using varies across peoples and cultures with similarities seen within same ethnic group spread across different geographical space.

There is a perception amongst herbal practitioners and users of herbals as medicines that such is safe and non-toxic, this may be incorrect in a number of cases $[\underline{6}, \underline{7}]$ either from dosage, reactions with other medicines of simply due to their composition. There have been surveys[8-16] conducted on different aspects of medicinal plant usage in South West Nigeria and Lagos State. The use of herbs as medicines and the history of such plants is often not well documented as written text in most rural communities. What usually happens in such communities is that herbal medical practitioners pass on the history/composition/usage of these herbal plants to their apprentices and the oral tradition continues. This imprecise mode of information dissemination/transfer in more cases than not leads to information/knowledge losses with its attendant implications in herbal health care practice/management.

This survey is aims at gathering information on medicinal plant and the ailments they are used to treat by the peoples of Lekki Oke and Isale Lekki of Lagos state in Nigeria.

\section{MATERIAL AND METHODS}

\section{Study location}

Two villages were used for this study, viz Lekki Oke and Isale Lekki, located in the Ibeju-Lekki Local Government area of Lagos State. The villages lie approximately between $4^{0} 15^{1} \mathrm{~N}$ and $4^{0} 17^{1} \mathrm{~N}$ and $13^{0} 15^{1} \mathrm{E}$ and $13^{0} 2^{1} \mathrm{E}$. They are bounded in the East by Epe Local Government, and in the South by the Atlantic Ocean. The people of the area are mainly ljebu speaking, with a sprinkling of other people from different parts of the country such as the Ilaje, Benin, Ondo, Egba, and Ibadan. Their socio-economic activities include mat weaving, soap making, concrete block making, goldsmithing, fishing, oil and cassava processing, etc. This indigenous people typically depend on plants for both feeding and medicinal purposes.

The method employed in this survey is a modified version of an earlier work [17]. The modification; this study focused on the totality of plant species (for medical uses) commonly used by the people in the study area for treatment of common ailments. Plant parts such as seeds, flowers, leaves, stem, inflorescence, rhizomes and florets of 60 plants were randomly collected within and around the beach at one location, and 65 plants species collected from marshy, swampy fresh water areas at the other area, i.e. Isale Lekki. A total number of 125 plant specimens collected were identified by the Lagos State University, Botany Department's herbarium. The local names of the plants were gotten from experienced adult male and female local traditional healers. The unidentified plant species were taken to herbarium, and texts such as: [18-20], and a staff of herbarium was also solicited in identifying them. Lastly, maps showing the geographical location of Lekki, Lagos State vegetation communities and Nigeria map were obtained from Nigerian conservation foundation library in Ibeju Lekki Local Government office and drawn to specifications. 


\section{RESULTS AND DISCUSSION}

The survey results are presented as figures and a table

Table 1: Showing names and uses of surveyed plants.

\begin{tabular}{|c|c|c|c|c|c|c|c|}
\hline $\mathbf{S} / \mathbf{n}$ & $\begin{array}{l}\text { Botanical } \\
\text { plant }\end{array}$ & Local name & $\begin{array}{l}\text { Plant } \\
\text { part } \\
\text { used }\end{array}$ & $\begin{array}{l}\text { Major } \\
\text { disorder } \\
\text { (Disease } \\
\text { used to } \\
\text { treat) }\end{array}$ & $\begin{array}{c}\text { Mode of } \\
\text { preparation/ } \\
\text { administrati } \\
\text { on }\end{array}$ & $\begin{array}{l}\text { Documented } \\
\text { literature } \\
\text { supporting } \\
\text { ethnomedicin } \\
\text { al usage }\end{array}$ & $\begin{array}{c}\text { Other } \\
\text { documente } \\
\text { d medical } \\
\text { uses }\end{array}$ \\
\hline 1 & $\begin{array}{l}\text { Bryophllum } \\
\text { pinnatum }\end{array}$ & Abamoda & $\begin{array}{l}\text { Leaf, } \\
\text { stem }\end{array}$ & & Decoction & & [21-28] \\
\hline 2 & $\begin{array}{l}\text { Citrus } \\
\text { aurantifolia }\end{array}$ & Osan-wewe & Fruit & & & & [29-32] \\
\hline 3 & $\begin{array}{l}\text { Napoleona } \\
\text { vogelii }\end{array}$ & Boribori & Bark & & & & {$[\underline{30}, \underline{32-35]}$} \\
\hline 4 & $\begin{array}{l}\text { Anacardiu } \\
m \\
\text { occidentale }\end{array}$ & Kaju & $\begin{array}{l}\text { Leaf, } \\
\text { bark }\end{array}$ & & $\begin{array}{l}\text { Soaked in } \\
\text { water, }\end{array}$ & & [36-42] \\
\hline 5 & $\begin{array}{l}\text { Azadiracht } \\
a \quad \text { indica }\end{array}$ & Dongoyaro & $\begin{array}{l}\text { Leaf, } \\
\text { bark }\end{array}$ & Yellow fever & $\begin{array}{l}\text { pulverized } \\
\text { and mixed } \\
\text { with potash, }\end{array}$ & [43-45] & [46-51] \\
\hline 6 & $\begin{array}{l}\text { Acanthosp } \\
\text { ermum } \\
\text { hispidum }\end{array}$ & $\begin{array}{l}\text { Dagunrogogo } \\
\text { ro }\end{array}$ & $\begin{array}{l}\text { Leaf, } \\
\text { root }\end{array}$ & & $\begin{array}{l}\text { mixed with } \\
\text { palm-wine }\end{array}$ & [52-54] & {$[\underline{55-62]}$} \\
\hline 7 & $\begin{array}{l}\text { Carica } \\
\text { papaya }\end{array}$ & Ibepe & Leaf & & & & [63-69] \\
\hline 8 & $\begin{array}{l}\text { Jatropha } \\
\text { curcas }\end{array}$ & Botuje & $\begin{array}{l}\text { Leaf, } \\
\text { root. }\end{array}$ & & Decoction & & [70-76] \\
\hline 9 & $\begin{array}{l}\text { Enantia } \\
\text { chlorantha }\end{array}$ & Osopupa & Bark & \multirow{6}{*}{ Malaria } & & {$[\underline{77}, \underline{78]}$} & [79-85] \\
\hline 10 & $\begin{array}{l}\text { Carrica } \\
\text { papaya }\end{array}$ & Ibepe & $\begin{array}{l}\text { Old } \\
\text { leaf }\end{array}$ & & \multirow{2}{*}{ Decoction } & & See 6 above \\
\hline 11 & $\begin{array}{l}\text { Citrus } \\
\text { sinensis }\end{array}$ & Osan - mimu & Fruit & & & [86-91] & {$[\underline{89}, \underline{92}, \underline{93}]$} \\
\hline 12 & Sida acuta & Isankotu & Root & & \multirow{2}{*}{$\begin{array}{l}\text { Decoction } \\
\text { and bath, } \\
\text { Soak in palm- } \\
\text { wine. }\end{array}$} & {$[94, \underline{95]}$} & [96-98] \\
\hline 13 & $\begin{array}{l}\text { Alstonia } \\
\text { boonei }\end{array}$ & Awun & Bark & & & [99-101] & [102-106] \\
\hline 14 & $\begin{array}{l}\text { Mangifera } \\
\text { indica }\end{array}$ & Mangoro & $\begin{array}{l}\text { Bark \& } \\
\text { leaf }\end{array}$ & & Decoction & & [107-113] \\
\hline 15 & $\begin{array}{l}\text { Uapaca } \\
\text { guineensis }\end{array}$ & Abo - emido & Fruit & & Decoction & & [114] \\
\hline
\end{tabular}




\begin{tabular}{|c|c|c|c|c|c|c|c|}
\hline 16 & $\begin{array}{l}\text { Alchornea } \\
\text { cordifolia }\end{array}$ & Irenleipa & Bark & \multirow{4}{*}{ Cough } & Chewed & [115] & [116-122] \\
\hline 17 & $\begin{array}{l}\text { Schwenkia } \\
\text { americana }\end{array}$ & Igbale - odan & Leaf & & Decoction & & [123-126] \\
\hline 18 & $\begin{array}{l}\text { Cylicodiscu } \\
s \\
\text { gabunensis }\end{array}$ & Olosan & $\begin{array}{l}\text { Leaf, } \\
\text { Bark }\end{array}$ & & $\begin{array}{l}\text { Milled, mixed } \\
\text { with water }\end{array}$ & & \\
\hline 19 & Allium cepa & Alubosa & Juice & & $\begin{array}{l}\text { Mixed with } \\
\text { Honey }\end{array}$ & [127-129] & \multirow[t]{2}{*}{ [130-137] } \\
\hline 20 & Allium cepa & Alubosa & Bulb & \multirow{5}{*}{$\begin{array}{l}\text { Dermatologic } \\
\text { al disorders }\end{array}$} & $\begin{array}{l}\text { Crushed, } \\
\text { applied to } \\
\text { affected part }\end{array}$ & {$[138,139]$} & \\
\hline 21 & $\begin{array}{l}\text { Eleusine } \\
\text { indica }\end{array}$ & Gbegi & $\begin{array}{l}\text { Whole } \\
\text { plant }\end{array}$ & & $\begin{array}{l}\text { Decoction } \\
\text { and bath } \\
\text { Milled and } \\
\text { dissolved in } \\
\text { water for bath }\end{array}$ & & [140] \\
\hline 22 & $\begin{array}{l}\text { Anthocleist } \\
\text { a sp }\end{array}$ & Akoko - edo & $\begin{array}{l}\text { Root, } \\
\text { bark }\end{array}$ & & \multirow{3}{*}{$\begin{array}{l}\text { Milled and } \\
\text { dissolved in } \\
\text { water for bath }\end{array}$} & & \\
\hline 23 & $\begin{array}{l}\text { Cymbopog } \\
\text { on } \\
\text { citratus }\end{array}$ & Kooko-oba & Root & & & & \\
\hline 24 & $\begin{array}{l}\text { Jatropha } \\
\text { curcas }\end{array}$ & Ose & Root & & & [141] & {$\left[70, \frac{71}{145}, 142-\right.$} \\
\hline 25 & $\begin{array}{l}\text { Talinum } \\
\text { fruiticosum }\end{array}$ & Gbure & Tuber & $\begin{array}{l}\text { Premenstrua } \\
\text { I syndrome }\end{array}$ & $\begin{array}{l}\text { Crushed and } \\
\text { drunk }\end{array}$ & & {$[146,147]$} \\
\hline 26 & $\begin{array}{l}\text { Enantia } \\
\text { chlorantha }\end{array}$ & Osapupa & Bark & \multirow{7}{*}{ Leprosy } & Decoction & & 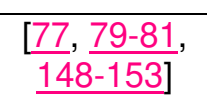 \\
\hline 27 & $\begin{array}{l}\text { Abrus } \\
\text { precatorius }\end{array}$ & Oju-ologbo & Seed & & Decoction & & [154-167] \\
\hline 28 & $\begin{array}{l}\text { Citrus } \\
\text { sinensis }\end{array}$ & Oronbo & Bark & & & & [168-171] \\
\hline 29 & $\begin{array}{l}\text { Gossypium } \\
\text { sp }\end{array}$ & Owu/koro & Root & & & & \\
\hline 30 & $\begin{array}{l}\text { Manihot } \\
\text { esculenta }\end{array}$ & Gbaguda & Tuber & & $\begin{array}{l}\text { Decoction } \\
\text { mixed with } \\
\text { salt }\end{array}$ & & {$[12,172]$} \\
\hline 31 & $\begin{array}{l}\text { Terminalia } \\
\text { catappa }\end{array}$ & Epo Akintola & Bark & & Decoction & [173] & \\
\hline 32 & $\begin{array}{l}\text { Chromolae } \\
\text { na odorata }\end{array}$ & & Leaf & & $\begin{array}{l}\text { Extract is } \\
\text { taken with } \\
\text { palm-wine }\end{array}$ & [174] & [175] \\
\hline 33 & $\begin{array}{l}\text { Lycopersic } \\
\text { um } \\
\text { esculentum }\end{array}$ & Tomato & $\begin{array}{l}\text { Leaf } \\
\text { juice }\end{array}$ & Ear ache & $\begin{array}{l}\text { Crushed, } \\
\text { applied as } \\
\text { drops at night }\end{array}$ & & [176-181] \\
\hline
\end{tabular}




\begin{tabular}{|c|c|c|c|c|c|c|c|}
\hline 34 & $\begin{array}{l}\text { Antiaris } \\
\text { welwitschii }\end{array}$ & & $\begin{array}{l}\text { Stem } \\
\text { bark }\end{array}$ & Purgative & $\begin{array}{l}\text { Dried, milled, } \\
\text { mixed with }\end{array}$ & & \\
\hline 35 & $\begin{array}{l}\text { Phyllanthus } \\
\text { amarus }\end{array}$ & Iyin-olobe & $\begin{array}{l}\text { Stem } \\
\text { bark }\end{array}$ & & $\begin{array}{l}\text { hot corn gruel } \\
\text { and orally } \\
\text { taken } \\
\text { morning \& } \\
\text { night }\end{array}$ & {$[182,183]$} & [184-195] \\
\hline 36 & $\begin{array}{l}\text { Allium } \\
\text { sativum }\end{array}$ & Ayuu & Bulb & \multirow{2}{*}{ Asthma } & \multirow{2}{*}{$\begin{array}{l}\text { Both mixed } \\
\text { with garlic } \\
\text { soup }\end{array}$} & & [196-204] \\
\hline 37 & $\begin{array}{l}\text { Ipomoea } \\
\text { batatas }\end{array}$ & Odukun & Root & & & & [205-207] \\
\hline 38 & $\begin{array}{l}\text { Gloriosa } \\
\text { superba }\end{array}$ & Ewe/aja & Root & \multirow{5}{*}{$\begin{array}{l}\text { Abdominal } \\
\text { disorder }\end{array}$} & Decoction & [208] & {$[209, \underline{210]}$} \\
\hline 39 & $\begin{array}{l}\text { Amaranthu } \\
\text { s spinosus }\end{array}$ & Epotete & Root & & & & [211-213] \\
\hline 40 & $\begin{array}{l}\text { Dracaena } \\
s p\end{array}$ & $\begin{array}{l}\text { Ope- } \\
\text { kannakan }\end{array}$ & Root & & $\begin{array}{l}\text { Mixed with a } \\
\text { pinch of table } \\
\text { salt }\end{array}$ & & \\
\hline 41 & $\begin{array}{l}\text { Terminalia } \\
\text { catappa }\end{array}$ & Ojuologbo & Root & & $\begin{array}{l}\text { Both cooked } \\
\text { with snail in }\end{array}$ & & [214-223] \\
\hline 42 & $\begin{array}{l}\text { Abrus } \\
\text { precatorius }\end{array}$ & & Leaf & & $\begin{array}{l}\text { situation } \\
\text { Soak in water }\end{array}$ & & $\frac{[154}{\frac{161}{2}, \frac{155}{166},}, \frac{157}{167}$, \\
\hline 43 & $\begin{array}{l}\text { Eleusine } \\
\text { indica }\end{array}$ & Gbegi & $\begin{array}{l}\text { Whole } \\
\text { plant }\end{array}$ & \multirow{2}{*}{ Rheumatism } & \multirow[b]{2}{*}{$\begin{array}{l}\text { Both, } \\
\text { Decoction } \\
\text { add table salt } \\
\text { to mopped } \\
\text { affected part }\end{array}$} & & [227] \\
\hline 44 & $\begin{array}{l}\text { Citrus } \\
\text { aurantifolia }\end{array}$ & Osan wewe & Fruit & & & & [228-231] \\
\hline 45 & $\begin{array}{l}\text { Bambusa } \\
\text { vulgaris }\end{array}$ & Oparun & Root & \multirow{2}{*}{$\begin{array}{l}\text { Respiratory } \\
\text { diseases }\end{array}$} & Decoction & {$[\underline{232}, \underline{233}$} & [234-238] \\
\hline 46 & $\begin{array}{l}\text { Allium } \\
\text { sativum }\end{array}$ & Ayuu & Bulb & & Decoction & [239-242] & See ---- above \\
\hline 47 & $\begin{array}{l}\text { Vitex } \\
\text { doniana }\end{array}$ & Oori, isigun & $\begin{array}{l}\text { Stem } \\
\text { bark }\end{array}$ & Convulsion & $\begin{array}{l}\text { Decoction } \\
\text { and mixed } \\
\text { with } \\
\text { cow/sheep } \\
\text { urine }\end{array}$ & & [242-249] \\
\hline 48 & $\begin{array}{l}\text { Symphonia } \\
\text { globulifera }\end{array}$ & Agberigbedi & $\begin{array}{l}\text { Stem } \\
\text { bark }\end{array}$ & \multirow[t]{2}{*}{ Anaemia } & $\begin{array}{l}\text { Decoction } \\
\text { and mixed } \\
\text { with milk }\end{array}$ & & [250-253] \\
\hline 49 & $\begin{array}{l}\text { Dioclea } \\
\text { reflexa }\end{array}$ & Arin & Seed & & $\begin{array}{l}\text { Dried, mixed } \\
\text { with malted } \\
\text { drink }\end{array}$ & & [254-256] \\
\hline 50 & $\begin{array}{l}\text { Thaumatoc } \\
\text { ocus } \\
\text { daniellii }\end{array}$ & Eeran & Fruit & Diabetes & $\begin{array}{l}\text { Soaked in } \\
\text { water }\end{array}$ & [257] & [258-262] \\
\hline
\end{tabular}




\begin{tabular}{|c|c|c|c|c|c|c|c|}
\hline 51 & $\begin{array}{l}\text { Carica } \\
\text { papaya }\end{array}$ & Ibepe & $\begin{array}{l}\text { Unripe } \\
\text { fruit }\end{array}$ & Jaundice & $\begin{array}{l}\text { Sliced and } \\
\text { soak in water }\end{array}$ & {$[263, \underline{264]}$} & $\frac{[63-65}{\underline{265-271]}}, \frac{67-69}{\underline{6}}$ \\
\hline 52 & $\begin{array}{l}\text { Citrus } \\
\text { aurantifolia }\end{array}$ & Osan wewe & Fruit & \multirow{2}{*}{ Obesity } & \multirow{2}{*}{$\begin{array}{l}\text { Decoction \& } \\
\text { mixed with } \\
\text { water }\end{array}$} & [272-275] & {$[273, \underline{276]}$} \\
\hline 53 & $\begin{array}{l}\text { Lycopersic } \\
\text { um } \\
\text { esculentum }\end{array}$ & Tomato & Fruit & & & [277] & \\
\hline 54 & $\begin{array}{l}\text { Elaeis } \\
\text { guineensis }\end{array}$ & Ope & Fruit & \multirow[t]{2}{*}{ Whitlow } & $\begin{array}{l}\text { Squeezed } \\
\text { and applied in } \\
\text { affected part }\end{array}$ & [278] & [279-281] \\
\hline 55 & $\begin{array}{l}\text { Citrus } \\
\text { aurantifolia }\end{array}$ & Osan wewe & Fruit & & $\begin{array}{l}\text { Cut and fixed } \\
\text { in affected } \\
\text { part }\end{array}$ & & {$[\underline{228}, \underline{282-284]}$} \\
\hline 56 & Allium cepa & Alubosa & Juice & \multirow[t]{2}{*}{$\begin{array}{l}\text { Erectile } \\
\text { dysfunction }\end{array}$} & \multirow{2}{*}{$\begin{array}{l}\text { Decoction } \\
\text { and mixed } \\
\text { with honey, or } \\
\text { corn gruel } \\
\text { and native } \\
\text { egg }\end{array}$} & [285] & \\
\hline 57 & $\begin{array}{l}\text { Citrus } \\
\text { aurantifolia }\end{array}$ & Osan wewe & Juice & & & & \\
\hline 58 & Musa spp & Ogede & Juice & $\begin{array}{l}\text { Facial } \\
\text { beauty }\end{array}$ & $\begin{array}{l}\text { Mixed with } \\
\text { honey }\end{array}$ & & \\
\hline 59 & $\begin{array}{l}\text { Corchorus } \\
\text { olitorus }\end{array}$ & Illa & Leaf & $\begin{array}{l}\text { Easy } \\
\text { parturition }\end{array}$ & $\begin{array}{l}\text { Squeezed in } \\
\text { water }\end{array}$ & & [286-294] \\
\hline 60 & $\begin{array}{l}\text { Citrus } \\
\text { aurantifolia }\end{array}$ & Osan wewe & \multirow[t]{2}{*}{ Fruit } & \multirow[t]{2}{*}{$\begin{array}{l}\text { Sickle cell } \\
\text { anaemia }\end{array}$} & \multirow{2}{*}{$\begin{array}{l}\text { Mixed with } \\
\text { egg yolk and } \\
\text { honey }\end{array}$} & & {$[\underline{228}, \underline{229}, \underline{284}] \underline{283}$} \\
\hline 61 & $\begin{array}{l}\text { Citrus } \\
\text { sinensis }\end{array}$ & Osan mumu & & & & [295] & \\
\hline 62 & Allium cepa & Alubosa & Bulb & Blurry vision & $\begin{array}{l}\text { Eat raw, drink } \\
\text { palm wine on } \\
\text { top }\end{array}$ & & \\
\hline 63 & $\begin{array}{l}\text { Carica } \\
\text { papaya }\end{array}$ & Ibepe & Seed & \multirow[t]{2}{*}{ Weight loss } & \multirow[t]{2}{*}{$\begin{array}{l}\text { Chewed and } \\
\text { drink }\end{array}$} & [296-298] & \\
\hline 64 & $\begin{array}{l}\text { Citrus } \\
\text { sinensis }\end{array}$ & Osan Mimu & Juice & & & [299-302] & {$[169, \underline{303-307]}$} \\
\hline
\end{tabular}




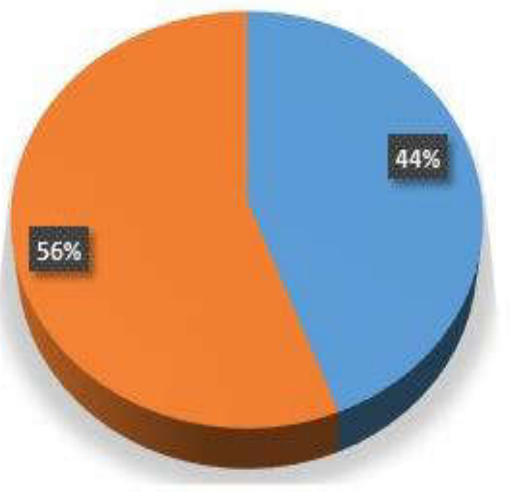

Figure 1: Pie chart depicting the percentage of plants surveyed with documented usage

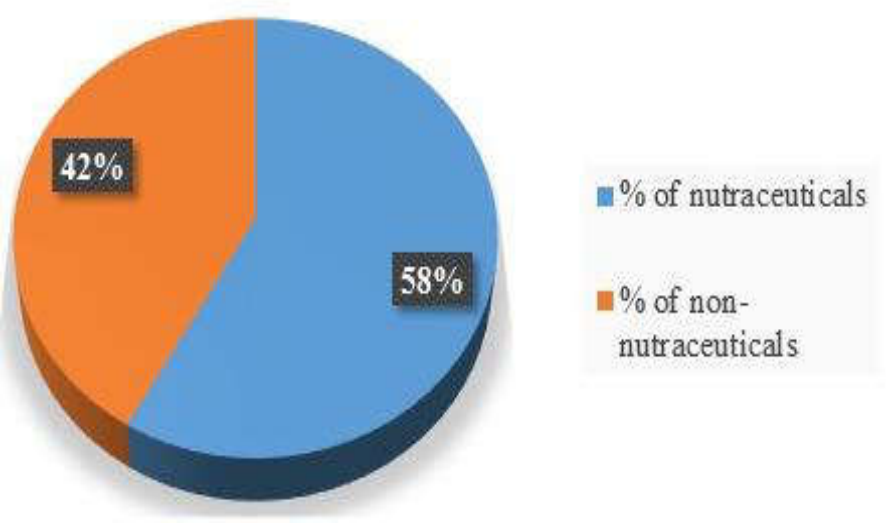

Figure 2: Pie chart depicting the percentage of plants surveyed that are nutraceuticals

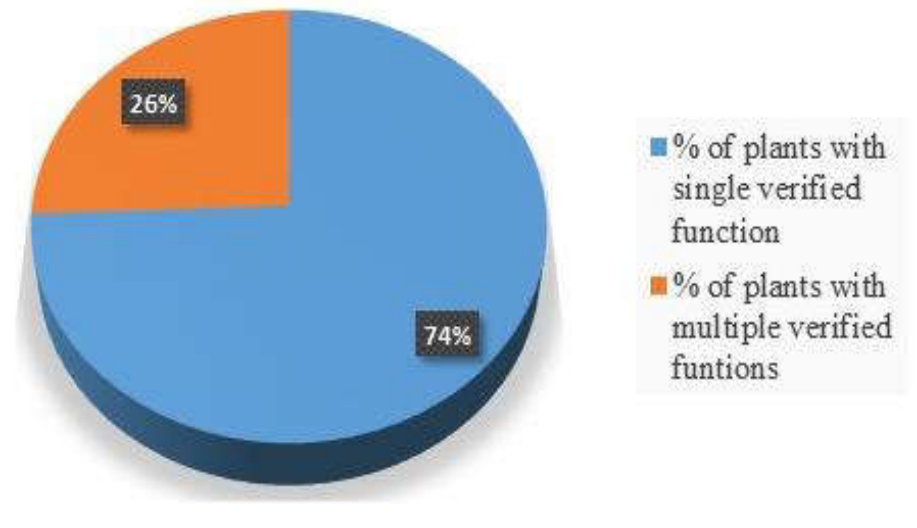

Fig 3: Pie chart showing percentages of plants surveyed with documented multiple medical uses.

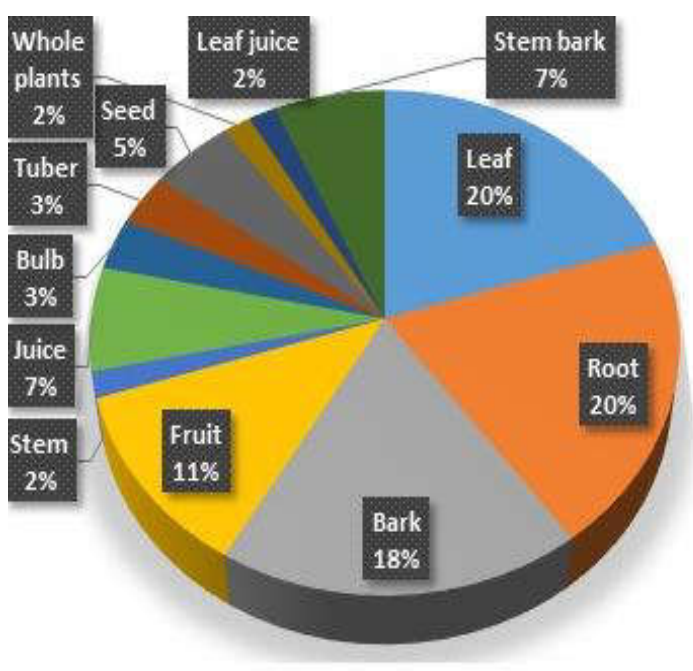

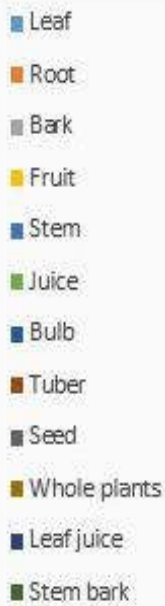

Fig 4: Pie chart showing documented plant parts

utilised in herbal therapy 


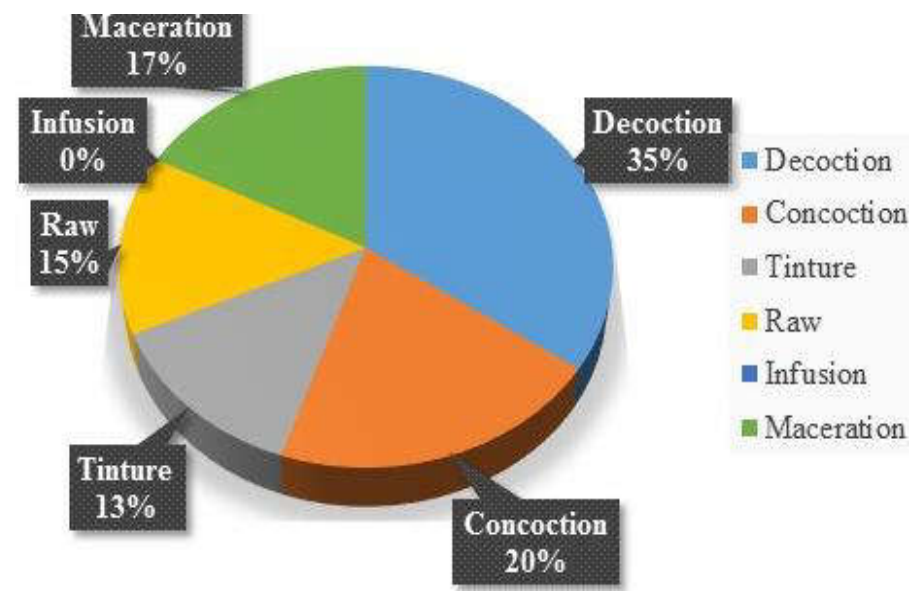

Fig 5: Pie chart showing percentages of preparation methods commonly employed

\section{DISCUSSION}

The advances in modern medicine and healthcare has not eradicated the use of plants as medicines by indigenous peoples in different parts of the world. Instead, there is a gradual shift to use of plants as alternate medicines and as candidates for drug discovery [308]. As modern cultures and technologies spread around the world, the breadth of knowledge store of native people diminishes daily as older generations pass away and younger generation slowly set aside their traditional ways and adopt new life styles. The indigenous people of Lekki and Isale Lekki are knowledgeable about their natural environment, but most of these knowledge (oral) not documented, and without adequate knowledge transfer plans to the younger ones in the society. Oral traditions more often than not are rarely documented, this is also applicable to the use of plants as herbal medicines.

The outcome of this survey showed that a plant may have more than one local name and performing different purposes within same ethnic people e.g. Carica papaya which serves as food, is also used as cure for malaria, dysentery, jaundice in children and weight loss (see table and figure 3 ). This is not unique to medicinal plants in Nigeria[309], as it is a common phenomenom among plants consequent upon the presence of secondary metabolites which in turn are implicated in the management of health issues. Some plants that serve as both food and medicine are also utilized as medicaments via the extraction of such nutraceuticals [310]. This concept of nutraceuticals accounts for $42 \%$ of the plants surveyed in these papers (Figure 2). Additionally, some plants belonging to different families may have similar uses e.g. Gloriosa superba [208-210] from family Liliaceae, and Amaranthus spinosus [211-213] (Amaranthaceae) both contain bioactive ingredients that make them effective for management of stomach disorder. These two are part of the $44 \%$ of the plants (figure 1) surveyed in this study with verified medicinal functions.

Synergistic action of secondary metabolites in plants, and the simplicity inherent in their preparation at the domestic levels using aqueous extraction, accounts for the $20 \%$ (concoctions) and $35 \%$ (decoctions) of the preparation modes of herbals by the peoples surveyed in this study (figure 5). The leaves and roots are the most commonly used parts of plants in making herbal preparations accounting for about $20 \%$ of the plant parts surveyed (figure 4) in this study.

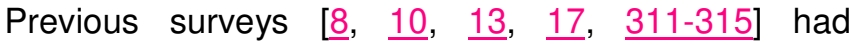
established the importance of herbs in the health and wellbeing of residents of Lagos state in Nigeria, with this study corroborating their importance using informatics of data in the public domain. The data from this survey suggests well structured documentation of the local information/knowledge of plants and their usage at the communal level as food and medicines.

\section{References}

1. Gossell-Williams, M., O. Simon, and M. West, The past and present use of plants for medicines. West Indian Medical Journal, 2006. 55(4): p. 217-218.

2. Iwu, M.M. African medicinal plants in the search for new drugs based on ethnobotanical leads. in Ciba Foundation Symposium 185-Ethnobotany and the Search for New Drugs: Ethnobotany and the Search for New Drugs: Ciba Foundation Symposium 185. 2007. Wiley Online Library.

3. Pirbaloutl, A., Medicinal plants used in Chaharmahal and Bakhtyari districts of Iran. Herba Polonica, 2009. 55(2): p. 69-77.

4. Raphael, E.C., Traditional medicine in Nigeria: current status and the future. Res $\mathrm{J}$

Pharmacol, 2011. 5(6): p. 90-4.

5. Koutsioni, Y. and V. Sommer, The bush as pharmacy and supermarket: mechanisms and functions of plant use by human and nonhuman primates at Gashaka, in Primates of Gashaka. 2011, Springer. p. 135-230.

6. Capasso, R., A.A. Izzo, L. Pinto, T. Bifulco, C. Vitobello, and N. Mascolo, Phytotherapy and quality of herbal medicines. Fitoterapia, 2000. 71: p. S58-S65.

7. Hussin, A.H., Adverse effects of herbs and drug-herbal interactions. Malaysian Journal of Pharmacy, 2001. 1(2): p. 39-44.

8. Ishola, I., I. Oreagba, A. Adeneye, C. Adirije, K. Oshikoya, and O. Ogunleye, Ethnopharmacological survey of herbal treatment of malaria in Lagos, Southwest 
Nigeria. Journal of Herbal Medicine, 2014. 4(4): p. 224-234.

9. Adeniyi, T., O. Oyebanji, and P. Adeonipekun, Floral diversity in the wetlands of Ibeju-Lekki Area, Lagos, Nigeria. Ife Journal of Science, 2016. 18(3): p. 729-737.

10. Olowokudejo, J., A. Kadiri, and V. Travih, An ethnobotanical survey of herbal markets and medicinal plants in Lagos State of Nigeria. Ethnobotanical leaflets, 2008. 2008(1): p. 116.

11. Gbolade, A.A., Inventory of antidiabetic plants in selected districts of Lagos State, Nigeria. Journal of Ethnopharmacology, 2009. 121(1): p. 135-139.

12. Abo, K., A. Fred-Jaiyesimi, and A. Jaiyesimi, Ethnobotanical studies of medicinal plants used in the management of diabetes mellitus in South Western Nigeria. Journal of Ethnopharmacology, 2008. 115(1): p. 67-71.

13. Oreagba, I.A., K.A. Oshikoya, and M. Amachree, Herbal medicine use among urban residents in Lagos, Nigeria. BMC Complementary and Alternative medicine, 2011. 11(1): p. 117.

14. Adetutu, A., W.A. Morgan, and O. Corcoran, Ethnopharmacological survey and in vitro evaluation of wound-healing plants used in South-western Nigeria. Journal of ethnopharmacology, 2011. 137(1): p. 50-56.

15. Ashidi, J., P. Houghton, P. Hylands, and T. Efferth, Ethnobotanical survey and cytotoxicity testing of plants of South-western Nigeria used to treat cancer, with isolation of cytotoxic constituents from Cajanus cajan Millsp. leaves. Journal of Ethnopharmacology, 2010. 128(2): p. 501-512.

16. Awoyemi, O., I. Abdulkarim, E. Ewa, and A. Aduloju, Ethnobotanical assessment of herbal plants in South-Western Nigeria. Academic research international, 2012. 2(3): p. 50.

17. Makinde, S., A. Ojekale, T. Oshinaike, and T. Awusinu, An Ethnomedical and Ethnobotanical survey of Plants Herbal Therapy used for Obesity, Asthma, Diabetes and Fertility by the Badagry people of Lagos State, Nigeria. Journal of Medicinal Plants, 2015. 3(5): p. $01-$ 06.

18. Burkill, H., the useful plants of tropical west African. Royal Botanical Garden, 1985, vol2, families AD: p. 254-257.

19. Z.O.Gbile, Vernacular names of Nigerian plants. 1984, Ibadan: Forestry Research Institute of Nigeria. 101.

20. Keay, R.W.J., D.P. Stanfield, and C.F.A. Onochie, Nigerian trees. Vol. I and II. 1964: Department of Forestry Research, Ibadan.

21. Akinpelu, D.A., Antimicrobial activity of Bryophyllum pinnatum leaves. Fitoterapia, 2000. 71(2): p. 193-194.

22. Akinsulire, O.R., I. Aibin, T. Adenipekun, T. Adelowotan, and T. Odugbemi, In vitro antimicrobial activity of crude extracts from plants Bryophyllum pinnatum and Kalanchoe crenata. African Journal of Traditional,
Complementary and Alternative Medicines, 2008. 4(3): p. 338-344.

23. Ogbonnia, S.O., J.I. Odimegwu, and V.N. Enwuru, Evaluation of hypoglycaemic and hypolipidaemic effects of aqueous ethanolic extracts of Treculia africana Decne and Bryophyllum pinnatum,/i> Lam. and their mixture on streptozotocin (STZ)-induced diabetic rats. African Journal of Biotechnology, 2008. 7(15).

24. Ojewole, J.A., P-2: Antihypertensive properties of Bryophyllum pinnatum \{(Lam) Oken\} leaf extracts. American Journal of Hypertension, 2002. 15(S3): p. 34A-34A.

25. Ojewole, J.A., Antinociceptive, antiinflammatory and antidiabetic effects of Bryophyllum pinnatum (Crassulaceae) leaf aqueous extract. Journal of ethnopharmacology, 2005. 99(1): p. 13-19.

26. Pal, S. and A.N. Chaudhuri, Studies on the anti-ulcer activity of a Bryophyllum pinnatum leaf extract in experimental animals. Journal of ethnopharmacology, 1991. 33(1): p. 97-102.

27. Pal, S., T. Sen, and A.N. Chaudhuri, Neuropsychopharmacological profile of the methanolic fraction of Bryophyllum pinnatum leaf extract. Journal of Pharmacy and pharmacology, 1999. 51(3): p. 313-318.

28. Yemitan, O. and H. Salahdeen, Neurosedative and muscle relaxant activities of aqueous extract of Bryophyllum pinnatum. Fitoterapia, 2005. 76(2): p. 187-193.

29. Akpona, H.A., J.D.T. Akpona, S.K. Awokou, A. Yemoa, and L. Dossa, Inventory, folk classification and pharmacological properties of plant species used as chewing stick in Benin Republic. J Med Plant Res, 2009. 3: p. 382-389.

30. Muganza, D.M., B. Fruth, J.N. Lami, G. Mesia, O. Kambu, G. Tona, et al., In vitro antiprotozoal and cytotoxic activity of 33 ethonopharmacologically selected medicinal plants from Democratic Republic of Congo. Journal of ethnopharmacology, 2012. 141(1): p. 301-308.

31. Akpuaka, M., S. Ezem, A. Ogbuagu, and U. Ekpunobi, The chemical constituents of some medicinal plants used in health management in South East Nigeria: A review. Journal of Chemical and Biomedical Science. Vol, 2015. 1(2): p. 17-24.

32. Koné, W.M., M. Vargas, and J. Keiser, Anthelmintic activity of medicinal plants used in Côte d'lvoire for treating parasitic diseases. Parasitology research, 2012. 110(6): p. 23512362.

33. Akah, P., O. Nnaeto, C. Nworu, and A. Ezike, Medicinal plants used in the traditional treatment of peptic ulcer diseases: a case study of Napoleona vogelii Hook and Planch (Lecythidaceae). Res J Pharmacol, 2007. 1(3): p. 67-74.

34. Enye, J., H. Chineke, D. Onubeze, and I. Nweke, Wound Healing Effect of Methanol 
Leaf Extract of Napoleona Vogelii Family (Lecythidaceae).

35. Owolabi, O.J., S.O. Inninh, O.N. Anaka, and O.A. Iyamu, Antidiabetic and hypolipidemic effects of methanol leaf extract of Napoleona vogelii (Lecythidaceae) Hook \& Planch on alloxan-induced diabetes mellitus in rats. Tropical Journal of Pharmaceutical Research, 2014. 13(11): p. 1903-1909.

36. Akinpelu, D.A., Antimicrobial activity of Anacardium occidentale bark. Fitoterapia, 2001. 72(3): p. 286-287.

37. Kamtchouing, P., S.D. Sokeng, P.F. Moundipa, P. Watcho, H.B. Jatsa, and D. Lontsi, Protective role of Anacardium occidentale extract against streptozotocininduced diabetes in rats. Journal of ethnopharmacology, 1998. 62(2): p. 95-99.

38. Mota, M., G. Thomas, and J. Barbosa Filho, Anti-inflammatory actions of tannins isolated from the bark of Anacardium occidentale $L$. J Ethnopharmacol, 1985. 13(3): p. 289-300.

39. Ojewole, J., Laboratory evaluation of the hypoglycemic effect of Anacardium occidentale Linn (Anacardiaceae) stem-bark extracts in rats. Methods and findings in experimental and clinical pharmacology, 2003. 25(3): p. 199-204.

40. Konan, N.A. and E.M. Bacchi, Antiulcerogenic effect and acute toxicity of a hydroethanolic extract from the cashew (Anacardium occidentale L.) leaves. Journal of ethnopharmacology, 2007. 112(2): p. 237-242.

41. Morais, T.C., N.B. Pinto, K.M.M. Carvalho, J.B. Rios, N.M.P. Ricardo, M.T.S. Trevisan, et al., Protective effect of anacardic acids from cashew (Anacardium occidentale) on ethanolinduced gastric damage in mice. Chemicobiological interactions, 2010. 183(1): p. 264269.

42. Cavalcante, A.A.M., G. Rübensam, B. Erdtmann, M. Brendel, and J.A. Henriques, Cashew (Anacardium occidentale) apple juice lowers mutagenicity of aflatoxin B1 in $S$. typhimurium TA102. Genetics and Molecular Biology, 2005. 28(2): p. 328-333.

43. Dua, V.K., A.C. Pandey, K. Raghavendra, A. Gupta, T. Sharma, and A.P. Dash, Larvicidal activity of neem oil (Azadirachta indica) formulation against mosquitoes. Malaria J, 2009. 8(1): p. 124.

44. Wandscheer, C.B., J.E. Duque, M.A. da Silva, Y. Fukuyama, J.L. Wohlke, J. Adelmann, et al., Larvicidal action of ethanolic extracts from fruit endocarps of Melia azedarach and Azadirachta indica against the dengue mosquito Aedes aegypti. Toxicon, 2004. 44(8): p. 829-835.

45. Ashorobi, R., Antipyretic effect of Azadirachta indica in bacteria endotoxin induced fever in the rat. Phytotherapy Research, 1998. 12(1): p. 41-43.

46. Abdel-Shafy, S. and A. Zayed, In vitro acaricidal effect of plant extract of neem seed oil (Azadirachta indica) on egg, immature, and adult stages of Hyalomma anatolicum excavatum (Ixodoidea: Ixodidae). Veterinary Parasitology, 2002. 106(1): p. 89-96.

47. Khillare, B. and T. Shrivastav, Spermicidal activity of Azadirachta indica (neem) leaf extract. Contraception, 2003. 68(3): p. 225229.

48. Bandyopadhyay, U., K. Biswas, R. Chatterjee, D. Bandyopadhyay, I. Chattopadhyay, C.K. Ganguly, et al., Gastroprotective effect of Neem (Azadirachta indica) bark extract: Possible involvement of $H_{+-} K+-$ ATPase inhibition and scavenging of hydroxyl radical. Life sciences, 2002. 71(24): p. 2845-2865.

49. Thakurta, P., P. Bhowmik, S. Mukherjee, T.K. Hajra, A. Patra, and P.K. Bag, Antibacterial, antisecretory and antihemorrhagic activity of Azadirachta indica used to treat cholera and diarrhea in India. Journal of ethnopharmacology, 2007. 111(3): p. 607-612.

50. Peer, P.A., P.C. Trivedi, P.B. Nigade, M.M. Ghaisas, and A.D. Deshpande, Cardioprotective effect of Azadirachta indica A. Juss. on isoprenaline induced myocardial infarction in rats. International journal of cardiology, 2008. 126(1): p. 123-126.

51. Kikuchi, T., K. Ishii, T. Noto, A. Takahashi, K. Tabata, T. Suzuki, et al., Cytotoxic and apoptosis-inducing activities of limonoids from the seeds of Azadirachta indica (neem). Journal of natural products, 2011. 74(4): p. 866-870.

52. Sanon, S., N. Azas, M. Gasquet, E. Ollivier, V. Mahiou, N. Barro, et al., Antiplasmodial activity of alkaloid extracts from Pavetta crassipes (K. Schum) and Acanthospermum hispidum (DC), two plants used in traditional medicine in Burkina Faso. Parasitology Research, 2003. 90(4): p. 314-317.

53. Fleischer, T., E. Ameade, and I. Sawer, Antimicrobial activity of the leaves and flowering tops of Acanthospermum hispidum. Fitoterapia, 2003. 74(1): p. 130-132.

54. Ganfon, H., J. Bero, A.T. Tchinda, F. Gbaguidi, J. Gbenou, M. Moudachirou, et al., Antiparasitic activities of two sesquiterpenic lactones isolated from Acanthospermum hispidum DC. Journal of ethnopharmacology, 2012. 141(1): p. 411-417.

55. Roy, H., A. Chakraborty, S. Bhanja, B.S. Nayak, S.R. Mishra, and P. Ellaiah, Preliminary phytochemical investigation and anthelmintic activity of Acanthospermum hispidum DC. Journal of Pharmaceutical Science and Technology, 2010. 2(5): p. 217221.

56. Summerfield, A., G.M. Keil, T.C. Mettenleiter, H.-J. Rziha, and A. Saalmüller, Antiviral activity of an extract from leaves of the tropical plant Acanthospermum hispidum. Antiviral research, 1997. 36(1): p. 55-62.

57. Lemonica, I. and C. Alvarenga, Abortive and teratogenic effect of Acanthospermum 
hispidum DC. and Cajanus cajan (L.) Millps. in pregnant rats. Journal of ethnopharmacology, 1994. 43(1): p. 39-44.

58. Deepa, N., N. Rajendran, T. Lata, and N. Jagannathan, Anti-bacterial and anti-fungal activities of ethyl acetate extract and the isolated fraction of Acanthospermum hispidum DC. Journal of Natural Remedies, 2004. 4(2): p. 190-194.

59. Arena, M.E., E. Cartagena, N. Gobbato, M. Baigori, J.C. Valdez, and A. Bardon, In vivo and in vitro antibacterial activity of acanthospermal $B$, a sesquiterpene lactone isolated from Acanthospermum hispidum. Phytotherapy Research, 2011. 25(4): p. 597602.

60. Bero, J., H. Ganfon, M.-C. Jonville, M. Frédérich, F. Gbaguidi, P. DeMol, et al., In vitro antiplasmodial activity of plants used in Benin in traditional medicine to treat malaria. Journal of Ethnopharmacology, 2009. 122(3): p. 439-444.

61. Deepa, N., Anti-tumor activity of Acanthospermum hispidum DC on dalton ascites lymphoma in mice. Natural Product Sciences, 2007. 13(3): p. 234-240.

62. ZHANG, Y.-y. and X.-y. LUO, Herbicidal Activity of Different Organs of Acanthospermum hispidum [J]. Acta Agriculturae Jiangxi, 2008. 11: p. 024.

63. Emeruwa, A., Antibacterial substance from Carica papaya fruit extract. Journal of natural products, 1982. 45(2): p. 123-127.

64. Lohiya, N., B. Manivannan, P. Mishra, N. Pathak, S. Sriram, S. Bhande, et al., Chloroform extract of Carica papaya seeds induces long-term reversible azoospermia in langur monkey. Asian Journal of Andrology, 2002. 4(1): p. 17-26.

65. Otsuki, N., N.H. Dang, E. Kumagai, A. Kondo, S. Iwata, and C. Morimoto, Aqueous extract of Carica papaya leaves exhibits anti-tumor activity and immunomodulatory effects. Journal of Ethnopharmacology, 2010. 127(3): p. 760-767.

66. Udoh, P. and A. Kehinde, Studies on antifertility effect of pawpaw seeds (Carica papaya) on the gonads of male albino rats. Phytotherapy Research, 1999. 13(3): p. 226228.

67. Gurung, S. and N. Škalko-Basnet, Wound healing properties of Carica papaya latex: in vivo evaluation in mice burn model. Journal of Ethnopharmacology, 2009. 121(2): p. 338-341.

68. Eno, A., O. Owo, E. Itam, and R. Konya, Blood pressure depression by the fruit juice of Carica papaya (L.) in renal and DOCA-induced hypertension in the rat. Phytotherapy Research, 2000. 14(4): p. 235-239.

69. Adeneye, A. and J. Olagunju, Preliminary hypoglycemic and hypolipidemic activities of the aqueous seed extract of Carica papaya Linn in Wistar rats. Biol Med, 2009. 1(1): p. 110.
70. Igbinosa, O., E. Igbinosa, and O. Aiyegoro, Antimicrobial activity and phytochemical screening of stem bark extracts from Jatropha curcas (Linn). African Journal of Pharmacy and Pharmacology, 2009. 3(2): p. 058-062.

71. Adebowale, K. and C. Adedire, Chemical composition and insecticidal properties of the underutilized Jatropha curcas seed oil. African Journal of Biotechnology, 2006. 5(10): p. 901906.

72. Goonasekera, M., V. Gunawardana, K. Jayasena, S. Mohammed, and S. Balasubramaniam, Pregnancy terminating effect of Jatropha curcas in rats. Journal of Ethnopharmacology, 1995. 47(3): p. 117-123.

73. Lin, J., F. Yan, L. Tang, and F. Chen, Antitumor effects of curcin from seeds of Jatropha curcas. Acta Pharmacologica Sinica, 2003. 24(3): p. 241-246.

74. Mujumdar, A. and A. Misar, Anti-inflammatory activity of Jatropha curcas roots in mice and rats. Journal of Ethnopharmacology, 2004. 90(1): p. 11-15.

75. Osoniyi, O. and F. Onajobi, Coagulant and anticoagulant activities in Jatropha curcas latex. Journal of Ethnopharmacology, 2003. 89(1): p. 101-105.

76. Fagbenro-Beyioku, A., W. Oyibo, and B. Anuforom, Disinfectant/antiparasitic activities of Jatropha curcas. East African medical journal, 1998. 75(9): p. 508-511.

77. Agbaje, E. and A. Onabanjo, The effects of extracts of Enantia chlorantha in malaria. Annals of tropical medicine and parasitology, 1991. 85(6): p. 585-590.

78. Adesokan, A., M. Akanji, V. Gupta, G. Singh, S. Singh, and A. Kaul, Antimalarial bioactivity of Enantia chlorantha stem bark. Medicinal plants: phytochemistry, pharmacology and therapeutics, Volume 1, 2010: p. 441-447.

79. Adesokan, A.A., M.A. Akanji, and M.T. Yakubu, Antibacterial potentials of aqueous extract of Enantia chlorantha stem bark. African Journal of Biotechnology, 2007. 6(22).

80. Atata, R.F., A. Sani, and S.M. Ajewole, Effect of stem bark extracts of Enantia chloranta on some clinical isolates. 2003.

81. Salman, T.M. and A.A. Adesokan, Sperm quality of male rats treated with aqueous extract of Enantia chlorantha stem bark. African Journal of Biotechnology, 2008. 7(7).

82. Moody, J., S. Bloomfield, and P. Hylands, Invitro evaluation of the antimicrobial activities of Enantia chlorantha Oliv. extractives. African journal of medicine and medical sciences, 1995. 24(3): p. 269-273.

83. Nkwengoua, E.T., I. Ngantchou, B. Nyasse, C. Denier, C. Blonski, and B. Schneider, In vitro inhibitory effects of palmatine from Enantia chlorantha on Trypanosoma cruzi and Leishmania infantum. Natural product research, 2009. 23(12): p. 1144-1150.

84. Ajaiyeoba, E., O. Abiodun, M. Falade, N. Ogbole, J. Ashidi, C. Happi, et al., In vitro 
cytotoxicity studies of 20 plants used in Nigerian antimalarial ethnomedicine. Phytomedicine, 2006. 13(4): p. 295-298.

85. Tan, P.V., M. Boda, and F.-X. Etoa, In vitro and in vivo anti-Helicobacter/Campylobacter activity of the aqueous extract of Enantia chlorantha. Pharmaceutical biology, 2010. 48(3): p. 349-356.

86. El-Akhal, F., A.E.O. Lalami, and R. Guemmouh, Larvicidal activity of essential oils of Citrus sinensis and Citrus aurantium (Rutaceae) cultivated in Morocco against the malaria vector Anopheles labranchiae (Diptera: Culicidae). Asian Pacific Journal of Tropical Disease, 2015. 5(6): p. 458-462.

87. Murugan, K., P.M. Kumar, K. Kovendan, D. Amerasan, J. Subrmaniam, and J.-S. Hwang, Larvicidal, pupicidal, repellent and adulticidal activity of Citrus sinensis orange peel extract against Anopheles stephensi, Aedes aegypti and Culex quinquefasciatus (Diptera: Culicidae). Parasitology research, 2012. 111(4): p. 1757-1769.

88. Amusan, A., A. Idowu, and F. Arowolo, Comparative toxicity effect of bush tea leaves (Hyptis suaveolens) and orange peel (Citrus sinensis) oil extract on larvae of the yellow fever mosquito Aedes aegypti. Tanzania Journal of Health Research, 2006. 7(3): p. 174-178.

89. Michaelakis, A., D. Papachristos, A. Kimbaris, G. Koliopoulos, A. Giatropoulos, and M.G. Polissiou, Citrus essential oils and four enantiomeric pinenes against Culex pipiens (Diptera: Culicidae). Parasitology research, 2009. 105(3): p. 769-773.

90. Kovendan, K., K. Murugan, P.M. Kumar, P. Thiyagarajan, and S.J. William, Ovicidal, repellent, adulticidal and field evaluations of plant extract against dengue, malaria and filarial vectors. Parasitology research, 2013. 112(3): p. 1205-1219.

91. Bilal, H., W. Akram, and S. Ali-Hassan, Larvicidal activity of Citrus limonoids against Aedes albopictus larvae. Journal of arthropodborne diseases, 2012. 6(2): p. 104.

92. Ekwenye, U.N. and O.V. Edeha, The antibacterial activity of crude leaf extract of Citrus sinensis (sweet orange). International Journal of Pharmacy and Bio Sciences, 2010. 1: p. $742-750$.

93. Akram, W., H.A. Khan, F. Hafeez, H. Bilal, Y.K. Kim, and J.-J. Lee, Potential of citrus seed extracts against dengue fever mosquito, Aedes albopictus (Skuse)(Culicidae: Diptera). Pak J Bot, 2010. 42(4): p. 3343-3348.

94. Karou, D., M.H. Dicko, S. Sanon, J. Simpore, and A.S. Traore, Antimalarial activity of Sida acuta Burm. f.(Malvaceae) and Pterocarpus erinaceus Poir.(Fabaceae). Journal of Ethnopharmacology, 2003. 89(2): p. 291-294.

95. Govindarajan, M., Larvicidal and repellent activities of Sida acuta Burm. F.(Family: Malvaceae) against three important vector mosquitoes. Asian Pacific Journal of Tropical Medicine, 2010. 3(9): p. 691-695.

96. Karou, D., A. Savadogo, A. Canini, S. Yameogo, C. Montesano, J. Simpore, et al., Antibacterial activity of alkaloids from Sida acuta. 2006.

97. Saganuwan, A.S. and G.M. Lawal, Evaluation of Sida acuta subspecie acuta leaf/flower combination for antimicrobial activity and phytochemical constituents. African Journal of Clinical and Experimental Microbiology, 2006. 7(2): p. 83-88.

98. Jindal, A. and P. Kumar, Antibacterial activity of Sida acuta Burm. f. against human pathogens. Asian J. Pharm. Clin. Res, 2012. 5: p. 33-35.

99. Bello, I., T. Oduola, O. Adeosun, N. Omisore, G. Raheem, and A. Ademosun, Evaluation of antimalarial activity of various fractions of Morinda lucida leaf extract and Alstonia boonei stem bark. Global Journal of Pharmacology, 2009. 3(3): p. 163-165.

100. Titanji, V.P., D. Zofou, and M.N. Ngemenya, The antimalarial potential of medicinal plants used for the treatment of malaria in Cameroonian folk medicine. African Journal of Traditional, Complementary, and Alternative Medicines, 2008. 5(3): p. 302.

101. Tepongning, R.N., L. Lucantoni, C.C. Nasuti, G.U. Dori, S.R. Yerbanga, G. Lupidi, et al., Potential of a Khaya ivorensis-Alstonia boonei extract combination as antimalarial prophylactic remedy. Journal of ethnopharmacology, 2011. 137(1): p. 743-751.

102. Olajide, O.A., S.O. Awe, J.M. Makinde, A.I. Ekhelar, A. Olusola, O. Morebise, et al., Studies on the anti-inflammatory, antipyretic and analgesic properties of Alstonia boonei stem bark. Journal of Ethnopharmacology, 2000. 71(1): p. 179-186.

103. Raji, Y., T.M. Salman, and O.S. Akinsomisoye, Reproductive functions in male rats treated with methanolic extract of Alstonia boonei stem bark. 2005.

104. Oigiangbe, O.N., I.B. Igbinosa, and M. Tamo, Insecticidal activity of the medicinal plant, Alstonia boonei De Wild, against Sesamia calamistis Hampson. Journal of Zhejiang University Science B, 2007. 8(10): p. 752-755.

105. Akah, P. and A. Nwambie, Nigerian plants with anti-convulsant property. Fitoterapia, 1993. 64(1): p. 42-44.

106. Asuzu, I. and C. Njoku, The anthelmintic effect of Alstonia boonei bark and Nauclea latifolia leaf aqueous extracts on Trichostrongylus infective larvae. Fitoterapia, 1996. 67(3): p. 220-222.

107. Okochi, V., A. Ojekale, O. Obolo, and U. Arukwe, The effect of Mangifera indica leaf and bark extracts on blood glucose level of rabbits. Nig. J. Hosp. Med, 1997. 7(2): p. 154157.

108. Parekh, J. and S. Chanda, In vitro antifungal activity of methanol extracts of some Indian 
medicinal plants against pathogenic yeast and moulds. African journal of Biotechnology, 2008. 7(23).

109. Mushore, J. and M. Matuvhunye, Antibacterial properties of Mangifera indica on Staphylococcus aureus. African Journal of Clinical and Experimental Microbiology, 2013. 14(2): p. 62-74.

110. Garrido, G., D. González, C. Delporte, N. Backhouse, G. Quintero, A.J. Núnez-Sellés, et al., Analgesic and anti-inflammatory effects of Mangifera indica L. extract (Vimang). Phytotherapy research, 2001. 15(1): p. 18-21.

111. Garrido, G., D. González, Y. Lemus, D. Garcıa, L. Lodeiro, G. Quintero, et al., In vivo and in vitro anti-inflammatory activity of Mangifera indica $L$. extract (VIMANG®). Pharmacological Research, 2004. 50(2): p. 143-149.

112. Sairam, K., S. Hemalatha, A. Kumar, T. Srinivasan, J. Ganesh, M. Shankar, et al., Evaluation of anti-diarrhoeal activity in seed extracts of Mangifera indica. Journal of ethnopharmacology, 2003. 84(1): p. 11-15.

113. Ojewole, J., Antiinflammatory, analgesic and hypoglycemic effects of Mangifera indica Linn.(Anacardiaceae) stem-bark aqueous extract. Methods and findings in experimental and clinical pharmacology, 2005. 27(8): p. 547-554.

114. Nkeh-Chungag, B.N., J.R. Temdie, C. SewaniRusike, Y.M. Fodjo, J.T. Mbafor, and J. Iputo, Analgesic, anti-inflammatory and antiulcer properties of the extract of Uapaca guineensis (Euphorbiaceae). Drugs, 2009. 9: p. 07.

115. Umukoro, S. and A.C. Aladeokin, Evaluation of the anti-stress and anticonvulsant activities of leaf extract of Alchornea cordifolia in mice. Journal of ethnopharmacology, 2010. 127(3): p. 768-770.

116. Agbor, G.A., T. Léopold, and N.Y. Jeanne, The antidiarrhoeal activity of Alchornea cordifolia leaf extract. Phytotherapy research, 2004. 18(11): p. 873-876.

117. Lamikanra, A., A. Ogundaini, and F. Ogungbamila, Antibacterial constituents of Alchornea cordifolia leaves. Phytotherapy research, 1990. 4(5): p. 198-200.

118. Osadebe, P. and F. Okoye, Anti-inflammatory effects of crude methanolic extract and fractions of Alchornea cordifolia leaves. Journal of ethnopharmacology, 2003. 89(1): p. 19-24.

119. Mavar-Manga, H., M. Haddad, L. Pieters, C. Baccelli, A. Penge, and J. Quetin-Leclercq, Anti-inflammatory compounds from leaves and root bark of Alchornea cordifolia (Schumach. \& Thonn.) Müll. Arg. Journal of ethnopharmacology, 2008. 115(1): p. 25-29.

120. Ebi, G., Antimicrobial activities of Alchornea cordifolia. Fitoterapia, 2001. 72(1): p. 69-72.

121. Eliakim-lkechukwu, C. and A. Obri, Histological changes in the pancreas following administration of ethanolic extract of
Alchornea cordifolia leaf in alloxan-induced diabetic wistar rats. Nigerian Journal of Physiological Sciences, 2009. 24(2).

122. Agyare, C., A. Owusu-Ansah, P. Ossei, J. Apenteng, and Y. Boakye, Wound healing and anti-infective properties of Myrianthus arboreus and Alchornea cordifolia. Medicinal Chemistry, 2014. 4(7): p. 533-539.

123. Asusheyi, B.I., G. Ndukwe, and O. Audu, Phytochemical studies and antimicrobial screening of Schwenkia americana Linn. J. Med. Plant Res, 2010. 4: p. 844-846.

124. Eriyamremu, G. and B.E. Iorliam, Biochemical evaluation of ulcer curative effect of ethanolic and aqueous extracts of Schwenkia americana Linn on experimental rats. Journal of Pharmacognosy and Phytochemistry, 2014. 3(4): p. 125-130.

125. Jimoh, A.O., A. Chika, M.T. Umar, I. Adebisi, and N. Abdullahi, Analgesic effects and antiinflammatory properties of the crude methanolic extract of Schwenckia americana Linn (Solanaceae). Journal of ethnopharmacology, 2011. 137(1): p. 543-546.

126. Bello, S., A. Chika, A. Jimoh, K. Abubakar, and I. Adebisi, Evaluation of hypoglycaemic and antihyperglycaemic activity of methanolic wholeplant extract of Schwenckia americana (Solanacae) in normal and alloxan-induced diabetic rats. African journal of pharmacy and pharmacology, 2013. 7: p. 2662-6.

127. Abdou, I., A. Abou-Zeid, M. El-Sherbeeny, and Z. Abou-El-Gheat, Antimicrobial activities of Allium sativum, Allium cepa, Raphanus sativus, Capsicum frutescens, Eruca sativa, Allium kurrat on bacteria. Qualitas Plantarum et Materiae Vegetabiles, 1972. 22(1): p. 29-35.

128. Adeleye, I., C. Onubogu, C. Ayolabi, A. Isawumi, and M. Nshiogu, Screening of crude extracts of twelve medicinal plants and "wondercure" concoction used in Nigeria unorthodox medicine for activity against mycobacterium tuberculosis isolated from tuberculosis patients sputum. African Journal of Infectious Diseases, 2008. 2(2).

129. Ram, A., S. Balachandar, P. Vijayananth, and V.P. Singh, Medicinal plants useful for treating chronic obstructive pulmonary disease (COPD): current status and future perspectives. Fitoterapia, 2011. 82(2): p. 141151.

130. Shri, R. and K.S. Bora, Neuroprotective effect of methanolic extracts of Allium cepa on ischemia and reperfusion-induced cerebral injury. Fitoterapia, 2008. 79(2): p. 86-96.

131. Ndukwu, B. and N. Ben-Nwadibia, Ethnomedicinal aspects of plants used as spices and condiments in the Niger delta area of Nigeria. Ethnobotanical Leaflets, 2005. 2005(1): p. 10.

132. Saad, B. and M.O. AlBureikan, Antimicrobial activity of onion juice (Allium cepa), honey, and onion-honey mixture on some sensitive 
and multi-resistant microorganisms. Life Science Journal, 2012. 9(2).

133. Phondani, P., R. Maikhuri, and C. Kala, Ethnoveterinary uses of medicinal plants among traditional herbal healers in Alaknanda catchment of Uttarakhand, India. African Journal of Traditional, Complementary and Alternative Medicines, 2010. 7(3).

134. Dowlathabad, M.R., Larvicidal activity of essential oils from Indian medicinal plants against Aedes aegypti L. Journal of Pharmacy Research Vol, 2009. 2(4).

135. Venkatanarayana, D., A.S. Kumar, and S.M. Lakshmi, Review on natural wound healing agents. International Journal of Phytopharmacy Research, 2010. 1: p. 1-4.

136. Woods-Panzaru, S., D. Nelson, G. McCollum, L.M. Ballard, B.C. Millar, Y. Maeda, et al., An examination of antibacterial and antifungal properties of constituents described in traditional Ulster cures and remedies. The Ulster medical journal, 2009. 78(1): p. 13.

137. Kumar, K.E., K. Harsha, and V. Sudheer, In vitro antioxidant activity and in vivo hepatoprotective activity of aqueous extract of Allium cepa bulb in ethanol induced liver damage in Wistar rats. Food Science and Human Wellness, 2013. 2(3): p. 132-138.

138. Abbasi, A.M., M. Khan, M. Ahmad, M. Zafar, S. Jahan, and S. Sultana, Ethnopharmacological application of medicinal plants to cure skin diseases and in folk cosmetics among the tribal communities of North-West Frontier Province, Pakistan. Journal of ethnopharmacology, 2010. 128(2): p. 322-335.

139. Campanati, A., A. Savelli, L. Sandroni, B. Marconi, A. Giuliano, K. Giuliodori, et al., Effect of Allium Cepa-Allantoin-Pentaglycan Gel on Skin Hypertrophic Scars: Clinical and Video-Capillaroscopic Results of an Open-Label, Controlled, Nonrandomized Clinical Trial. Dermatologic Surgery, 2010. 36(9): p. 1439-1444.

140. Mabeku, L.B.K., K.J. Roger, and O.E.J. Louis, Screening of some plants used in the Cameroonian Folk medicine for the treatment of infectious diseases. International Journal of Biology, 2011. 3(4): p. p13.

141. Okore, V., I. Umeh, and C. Nwakile, Antistaphylococcal activity of Jatropha curcas latex in the presence of some surfactants or human serum: Implications for treatment of skin infections. Bio-Research, 2007. 5(2): p. 285-289.

142. Sundar, V.J., C. Muralidharan, and A.B. Mandal, Eco-benign stabilization of skin protein-role of Jatropha curcas oil as a cotanning agent. Industrial Crops and Products, 2013. 47: p. 227-231.

143. Foidl, N., G. Foidl, M. Sanchez, M. Mittelbach, and S. Hackel, Jatropha curcas L. as a source for the production of biofuel in Nicaragua.
Bioresource Technology, 1996. 58(1): p. 77 82.

144. Kumar, A. and S. Sharma, An evaluation of multipurpose oil seed crop for industrial uses (Jatropha curcas L.): a review. Industrial crops and products, 2008. 28(1): p. 1-10.

145. King, A.J., W. He, J.A. Cuevas, M. Freudenberger, D. Ramiaramanana, and I.A. Graham, Potential of Jatropha curcas as a source of renewable oil and animal feed. Journal of experimental botany, 2009. 60(10): p. 2897-2905.

146. Okoli, R., O. Aigbe, J. Ohaju-Obodo, and J. Mensah, Medicinal herbs used for managing some common ailments among Esan people of Edo State, Nigeria. Pakistan Journal of Nutrition, 2007. 6(5): p. 490-496.

147. Afolabi, O., O. Oloyede, K. Jaiyesimi, T. Obafemi, J. Awe, and A. Fadaka, ANTAGONISTIC POTENTIALS OF TALINUM TRIANGULARE EXTRACTS AGAINST IRON II-INDUCED OXIDATIVE STRESS IN TISSUE HOMOGENATES OF WISTAR ALBINO RATIN VITRO. 2015.

148. Tan, P.V., B. Nyasse, G. Enow-Orock, P. Wafo, and E. Forcha, Prophylactic and healing properties of a new anti-ulcer compound from Enantia chlorantha in rats. Phytomedicine, 2000. 7(4): p. 291-296.

149. Nyasse, B., E. Nkwengoua, B. Sondengam, C. Denier, and M. Willson, Modified berberine and protoberberines from Enantia chlorantha as potential inhibitors of Trypanosoma brucei. Die Pharmazie, 2002. 57(6): p. 358-361.

150. Agbaje, E. and A. Onabanjo, Analgesic and antipyretic actions of Enantia chlorantha extract in some laboratory animals. Nigerian Journal of Natural Products and Medicine, 1998. 2(1): p. 24-25.

151. Din, N., S. Dibong, E.M. Mpondo, R. Priso, N. Kwin, and A. Ngoye, Inventory and identification of plants used in the treatment of diabetes in Douala town (Cameroon). European Journal of Medicinal Plants, 2011. 1(3): p. 60-73.

152. Siminialayi, I. and E. Agbaje, Gastroprotective effects of the ethanolic extract of Enantia chlorantha in rats. West African Journal of Pharmacology and Drug Research, 2005. 20(1): p. 35-38.

153. Olanlokun, J.O. and S.F. Akomolafe, Antioxidant potentials of various solvent extracts from stem bark of Enantia chlorantha. Journal of Biomedical Science and Engineering, 2013. 2013.

154. Kuo, S.-C., S.-C. Chen, L.-H. Chen, J.-B. Wu, J.-P. Wang, and C.-M. Teng, Potent antiplatelet, anti-inflammatory and antiallergic isoflavanquinones from the roots of Abrus precatorius. Planta medica, 1995. 61(4): p. 307-312.

155. Ratnasooriya, W., A. Amarasekera, N. Perera, and G. Premakumara, Sperm antimotility properties of a seed extract of Abrus 
precatorius. Journal of ethnopharmacology, 1991. 33(1): p. 85-90.

156. Adelowotan, O., I. Aibinu, E. Adenipekun, and T. Odugbemi, The in-vitro antimicrobial activity of Abrus precatorius (L) fabaceae extract on some clinical pathogens. The Nigerian postgraduate medical journal, 2008. 15(1): p. 32-37.

157. Anam, E., Anti-inflammatory activity of compounds isolated from the aerial parts of Abrus precatorius (Fabaceae). Phytomedicine, 2001. 8(1): p. 24-27.

158. Nwodo, O. and E. Alumanah, Studies on Abrus precatorius seeds. II: Antidiarrhoeal activity. Journal of ethnopharmacology, 1991. 31(3): p. 395-398.

159. Limmatvapirat, C., S. Sirisopanaporn, and P. Kittakoop, Antitubercular and antiplasmodial constituents of Abrus precatorius. Planta medica, 2004. 70(3): p. 276-278.

160. Pal, R.S., G. Ariharasivakumar, K. Girhepunje, and A. Upadhyay, In-vitro antioxidative activity of phenolic and flavonoids compounds extracted from seeds of Abrus precatorius. Int. J. Pharm. Pharm. Sci, 2009. 1(2): p. 136-140.

161. Rao, M., Antifertility effects of alcoholic seed extract of Abrus precatorius Linn. in male albino rats. Acta europaea fertilitatis, 1986. 18(3): p. 217-220.

162. Reddy, V.S. and M. Sirsi, Effect of Abrus precatorius $L$. on experimental tumors. Cancer research, 1969. 29(7): p. 1447-1451.

163. Sinha, S. and R. Mathur, Effect of steroidal fraction of seeds of Abrus precatorius Linn. on rat testis. Indian journal of experimental biology, 1990. 28(8): p. 752-756.

164. Okoko, I.-I., A. Osinubi, O. Olabiyi, T. Kusemiju, C. Noronha, and A. Okanlawon, Antiovulatory and anti-implantation potential of the methanolic extract of seeds of Abrus precatorius in the rat. Endocrine practice, 2010. 16(4): p. 554-560.

165. Monago, C. and E. Alumanah, Antidiabetic effect of chloroform-methanol extract of Abrus precatorius linn seed in alloxan diabetic rabbit. J. Appl. Sci. Environ. Mgt, 2005. 9(1): p. 8588.

166. Singh, S. and D. Singh, Effect of molluscicidal components of Abrus precatorius, Argemone mexicana and Nerium indicum on certain biochemical parameters of Lymnaeu acuminata. Phytotherapy Research, 1999. 13(3): p. 210-213.

167. Gul, M.Z., F. Ahmad, A.K. Kondapi, I.A. Qureshi, and I.A. Ghazi, Antioxidant and antiproliferative activities of Abrus precatorius leaf extracts-an in vitro study. BMC complementary and alternative medicine, 2013. 13(1): p. 53.

168. Singh, P., R. Shukla, B. Prakash, A. Kumar, S. Singh, P.K. Mishra, et al., Chemical profile, antifungal, antiaflatoxigenic and antioxidant activity of Citrus maxima Burm. and Citrus sinensis (L.) Osbeck essential oils and their cyclic monoterpene, DL-limonene. Food and Chemical Toxicology, 2010. 48(6): p. 17341740.

169. Parmar, H.S. and A. Kar, Antidiabetic potential of Citrus sinensis and Punica granatum peel extracts in alloxan treated male mice. Biofactors, 2007. 31(1): p. 17-24.

170. Parmar, H.S. and A. Kar, Medicinal values of fruit peels from Citrus sinensis, Punica granatum, and Musa paradisiaca with respect to alterations in tissue lipid peroxidation and serum concentration of glucose, insulin, and thyroid hormones. Journal of Medicinal Food, 2008. 11(2): p. 376-381.

171. Oboh, G. and A. Ademosun, Phenolic-rich extracts from orange peels (Citrus sinensis) inhibit key enzymes linked to non-insulin dependent diabetes mellitus (NIDDM) and hypertension. La Rivista Italiana Delle Sostanze Grasse, 2011. 88: p. 16-23.

172. Marie-Magdeleine, C., L. Udino, L. Philibert, B. Bocage, and $\mathrm{H}$. Archimede, In vitro effects of Cassava (Manihot esculenta) leaf extracts on four development stages of Haemonchus contortus. Veterinary parasitology, 2010. 173(1): p. 85-92.

173. Swamy, V., S.M. Ahmed, P. Gopkumar, R. Dhanapal, V. Chandrashekar, and T.S. Rao, Antidiarrhoeal activity of Terminalia catappa Linn. leaf extracts in rats. Asian Journal of Chemistry, 2006. 18(2): p. 1236.

174. Atindehou, M., L. Lagnika, B. Guérold, J.M. Strub, M. Zhao, A. Van Dorsselaer, et al., Isolation and identification of two antibacterial agents from Chromolaena odorata L. active against four diarrheal strains. 2013.

175. Akah, P., Mechanism of hemostatic activity of Eupatorium odoratum. Pharmaceutical Biology, 1990. 28(4): p. 253-256.

176. Guil-Guerrero, J. and M. Rebolloso-Fuentes, Nutrient composition and antioxidant activity of eight tomato (Lycopersicon esculentum) varieties. Journal of Food Composition and Analysis, 2009. 22(2): p. 123-129.

177. Ferreres, F., M. Taveira, D.M. Pereira, P.c. Valentão, and P. B. Andrade, Tomato (Lycopersicon esculentum) seeds: new flavonols and cytotoxic effect. Journal of agricultural and food chemistry, 2010. 58(5): p. 2854-2861.

178. Mazzetti, S., S. Frigerio, M. Gelati, A. Salmaggi, and L. Vitellaro-Zuccarello, Lycopersicon esculentum lectin: an effective and versatile endothelial marker of normal and tumoral blood vessels in the central nervous system. European Journal of Histochemistry, 2009. 48(4): p. 423-428.

179. Spinu, K., V. Vorozhbit, T. Grushko, P. Kintia, P. Skofertsa, V. Vutkaryov, et al., Antiviral activity of tomatoside from Lycopersicon esculentum Mill, in Saponins Used in Traditional and Modern Medicine. 1996, Springer. p. 505-509. 
180. Salawu, E.O., O.A. Adeeyo, O.P. Falokun, U.A. Yusuf, A. Oyerinde, and A.A. Adeleke, Tomato (Lycopersicon esculentum) prevents lead-induced testicular toxicity. Journal of human reproductive sciences, 2009. 2(1): p. 30.

181. Taveira, M., L.s.R. Silva, L.s.A. Vale-Silva, E.n. Pinto, P.c. Valentão, F. Ferreres, et al., Lycopersicon esculentum seeds: an industrial byproduct as an antimicrobial agent. Journal of agricultural and food chemistry, 2010. 58(17): p. 9529-9536.

182. Odetola, A. and S. Akojenu, Anti-diarrhoeal and gastro-intestinal potentials of the aqueous extract of Phyllanthus amarus (Euphorbiaceae). African journal of medicine and medical sciences, 2000. 29(2): p. 119122.

183. Raphael, K.R. and R. Kuttan, Inhibition of experimental gastric lesion and inflammation by Phyllanthus amarus extract. Journal of ethnopharmacology, 2003. 87(2): p. 193-197.

184. Thyagarajan, S., T. Thirunalasundari, S. Subramanian, P. Venkateswaran, and B. Blumberg, Effect of Phyllanthus amarus on chronic carriers of hepatitis $B$ virus. The Lancet, 1988. 332(8614): p. 764-766.

185. Srividya, N.a. and S. Periwal, Diuretic, hypotensive and hypoglycaemic effect of Phyllanthus amarus. Indian Journal of Experimental Biology, 1995. 33(11): p. 861864.

186. Adeneye, A., O. Amole, and A. Adeneye, Hypoglycemic and hypocholesterolemic activities of the aqueous leaf and seed extract of Phyllanthus amarus in mice. Fitoterapia, 2006. 77(7): p. 511-514.

187. Thamlikitkul, V., S. Wasuwat, and P. Kanchanapee, Efficacy of Phyllanthus amarus for eradication of hepatitis $B$ virus in chronic carriers. Journal of the Medical Association of Thailand $=$ Chotmaihet thangphaet, 1991. 74(9): p. 381-385.

188. Rajeshkumar, N. and R. Kuttan, Phyllanthus amarus extract administration increases the life span of rats with hepatocellular carcinoma. Journal of ethnopharmacology, 2000. 73(1): p. 215-219.

189. Raphael, K.R., M. Sabu, and R. Kuttan, Hypoglycemic effect of methanol extract of Phyllanthus amarus Schum \& Thonn on alloxan induced diabetes mellitus in rats and its relation with antioxidant potential. Indian journal of experimental biology, 2002. 40(8): $p$. 905-909.

190. Kassuya, C.A., D.F. Leite, L.V. de Melo, V.L. Rehder, and J.B. Calixto, Anti-inflammatory properties of extracts, fractions and lignans isolated from Phyllanthus amarus. Planta medica, 2005. 71(8): p. 721-726.

191. Kumar, K.H. and R. Kuttan, Protective effect of an extract of Phyllanthus amarus against radiation-induced damage in mice. Journal of radiation research, 2004. 45(1): p. 133-139.
192. Notka, F., G. Meier, and R. Wagner, Inhibition of wild-type human immunodeficiency virus and reverse transcriptase inhibitor-resistant variants by Phyllanthus amarus. Antiviral research, 2003. 58(2): p. 175-186.

193. Adeneye, A.A. and A.S. Benebo, Protective effect of the aqueous leaf and seed extract of Phyllanthus amarus on gentamicin and acetaminophen-induced nephrotoxic rats. Journal of ethnopharmacology, 2008. 118(2): p. 318-323.

194. Oluwafemi, F. and F. Debiri, Antimicrobial Effect of Phyllanthus amarus and Parquetina nigrescens on Salmonella typhi. African Journal of Biomedical Research, 2008. 11(2).

195. Rao, M.V. and K.M. Alice, Contraceptive effects of Phyllanthus amarus in female mice. Phytotherapy Research, 2001. 15(3): p. 265267.

196. Cavallito, C.J. and J.H. Bailey, Allicin, the antibacterial principle of Allium sativum. I. Isolation, physical properties and antibacterial action. Journal of the American Chemical Society, 1944. 66(11): p. 1950-1951.

197. Sheela, C. and K. Augusti, Antidiabetic effects of S-allyl cysteine sulphoxide isolated from garlic Allium sativum Linn. Indian journal of experimental biology, 1992. 30(6): p. 523-526.

198. Wargovich, M.J., Diallyl sulfide, a flavor component of garlic (Allium sativum), inhibits dimethyihydrazine-induced colon cancer. Carcinogenesis, 1987. 8(3): p. 487-489.

199. Eidi, A., M. Eidi, and E. Esmaeili, Antidiabetic effect of garlic (Allium sativum L.) in normal and streptozotocin-induced diabetic rats. Phytomedicine, 2006. 13(9): p. 624-629.

200. Bordia, A., S. Verma, and K. Srivastava, Effect of garlic (Allium sativum) on blood lipids, blood sugar, fibrinogen and fibrinolytic activity in patients with coronary artery disease. Prostaglandins, leukotrienes and essential fatty acids, 1998. 58(4): p. 257-263.

201. Lau, B.H., P.P. Tadi, and J.M. Tosk, Allium sativum (garlic) and cancer prevention. Nutrition research, 1990. 10(8): p. 937-948.

202. Koscielny, J., D. Klüßendorf, R. Latza, R. Schmitt, H. Radtke, G. Siegel, et al., The antiatherosclerotic effect of Allium sativum. Atherosclerosis, 1999. 144(1): p. 237-249.

203. Iqbal, Z., Q.K. Nadeem, M. Khan, M. Akhtar, and F.N. Waraich, In vitro anthelmintic activity of Allium sativum, Zingiber officinale, Curcurbita mexicana and Ficus religiosa. Int $\mathrm{J}$ Agri Biol, 2001. 3(4): p. 454-457.

204. Amonkar, S. and E. Reeves, Mosquito control with active principle of garlic, Allium sativum. Journal of economic entomology, 1970. 63(4): p. $1172-1175$.

205. Matsui, T., S. Ebuchi, M. Kobayashi, K. Fukui, K. Sugita, N. Terahara, et al., Antihyperglycemic effect of diacylated anthocyanin derived from Ipomoea batatas cultivar Ayamurasaki can be achieved through the $\alpha$ glucosidase inhibitory action. Journal of 
agricultural and food chemistry, 2002. 50(25): p. 7244-7248.

206. Yoshimoto, M., S. Okuno, M. Yoshinaga, O. Yamakawa, M. Yamaguchi, and J. YAMADA, Antimutagenicity of sweetpotato (Ipomoea batatas) roots. Bioscience, biotechnology, and biochemistry, 1999. 63(3): p. 537-541.

207. Kurata, R., M. Adachi, O. Yamakawa, and M. Yoshimoto, Growth suppression of human cancer cells by polyphenolics from sweetpotato (Ipomoea batatas L.) leaves. Journal of Agricultural and Food Chemistry, 2007. 55(1): p. 185-190.

208. Khan, H., M. Ali Khan, T. Mahmood, and M.I. Choudhary, Antimicrobial activities of Gloriosa superba Linn (Colchicaceae) extracts. Journal of enzyme inhibition and medicinal chemistry, 2008. 23(6): p. 855-859.

209. Joshi, C., E.S. Priya, and C. Mathela, Isolation and anti-inflammatory activity of colchicinoids from Gloriosa superba seeds. Pharmaceutical biology, 2010. 48(2): p. 206-209.

210. Pawar, B.M., V.P. Wavhal, N.D. Pawar, M.R. Agarwal, P.B. Shinde, and H.V. Kamble, Anthelmintic activity of Gloriosa superba Linn (Liliaceae). International Journal of PharmTech Research, 2010. 2(2): p. 14831487.

211. Hilou, A., O. Nacoulma, and T. Guiguemde, In vivo antimalarial activities of extracts from Amaranthus spinosus L. and Boerhaavia erecta $L$. in mice. Journal of ethnopharmacology, 2006. 103(2): p. 236-240.

212. Zeashan, H., G. Amresh, S. Singh, and C.V. Rao, Hepatoprotective activity of Amaranthus spinosus in experimental animals. Food and Chemical Toxicology, 2008. 46(11): p. 34173421.

213. Sangameswaran, B. and B. Jayakar, Antidiabetic, anti-hyperlipidemic and spermatogenic effects of Amaranthus spinosus Linn. on streptozotocin-induced diabetic rats. Journal of natural medicines, 2008. 62(1): p. 79-82.

214. Babayi, H., I. Kolo, J. Okogun, and U. Ijah, The antimicrobial activities of methanolic extracts of Eucalyptus camaldulensis and Terminalia catappa against some pathogenic microorganisms. 2004.

215. Nagappa, A., P. Thakurdesai, N.V. Rao, and J. Singh, Antidiabetic activity of Terminalia catappa Linn fruits. Journal of ethnopharmacology, 2003. 88(1): p. 45-50.

216. Kinoshita, S., Y. Inoue, S. Nakama, T. Ichiba, and Y. Aniya, Antioxidant and hepatoprotective actions of medicinal herb, Terminalia catappa $L$. from Okinawa Island and its tannin corilagin. Phytomedicine, 2007. 14(11): p. 755-762.

217. Fan, Y., L. Xu, J. Gao, Y. Wang, X. Tang, X. Zhao, et al., Phytochemical and antiinflammatory studies on Terminalia catappa. Fitoterapia, 2004. 75(3): p. 253-260.
218. Lin, C.-C., Y.-F. Hsu, and T.-C. Lin, Antioxidant and free radical scavenging effects of the tannins of Terminalia catappa $L$. Anticancer research, 2000. 21(1A): p. 237243.

219. Ahmed, S.M., B. Vrushabendra Swamy, P. Gopkumar, R. Dhanapal, and V. Chandrashekara, Anti-diabetic activity of Terminalia catappa Linn. leaf extracts in alloxan-induced diabetic rats. 2005.

220. Yang, S.-F., M.-K. Chen, Y.-S. Hsieh, J.-S. Yang, A.-I. Zavras, Y.-H. Hsieh, et al., Antimetastatic effects of Terminalia catappa $L$. on oral cancer via a down-regulation of metastasis-associated proteases. Food and Chemical Toxicology, 2010. 48(4): p. 10521058.

221. Chu, S.-C., S.-F. Yang, S.-J. Liu, W.-H. Kuo, Y.-Z. Chang, and Y.-S. Hsieh, In vitro and in vivo antimetastatic effects of Terminalia catappa $L$. leaves on lung cancer cells. Food and chemical toxicology, 2007. 45(7): p. 11941201.

222. Annegowda, H., M. Mordi, S. Ramanathan, and S. Mansor, Analgesic and antioxidant properties of ethanolic extract of Terminalia catappa L. leaves. International Journal of pharmacology, 2010. 6(6): p. 910-915.

223. Mudi, S. and A. Muhammad, Antimalaria activity of ethanolic extracts of leaves of terminalia catappa. I. combretaceae (indian almond). Bayero Journal of Pure and Applied Sciences, 2009. 2(1): p. 14-18.

224. Parekh, J., D. Jadeja, and S. Chanda, Efficacy of aqueous and methanol extracts of some medicinal plants for potential antibacterial activity. Turkish Journal of Biology, 2006. 29(4): p. 203-210.

225. Lin, J.Y., T.C. Lee, and T.C. Tung, ISOLATION OF ANTITUMOR PROTEINS ABRIN-A AND ABRIN-B FROM ABRUS PRECATORIUS*. International journal of peptide and protein research, 1978. 12(5): $p$. 311-317.

226. Saganuwan, S.A., P.A. Onyeyili, E.G. Ameh, and E. Udok Etuk, In vivo antiplasmodial activity by aqueous extract of Abrus precatorius in mice. Revista latinoamericana de química, 2011. 39(1-2): p. 32-44.

227. OKOKON, J.O. and I. EFFIONG, Antiplasmodial and antidiabetic activities of Eleusine indica. International Journal of Drug Development and Research, 2010.

228. Onyeagba, R., O. Ugbogu, C. Okeke, and O. Iroakasi, Studies on the antimicrobial effects of garlic (Allium sativum Linn), ginger (Zingiber officinale Roscoe) and lime (Citrus aurantifolia Linn). African Journal of Biotechnology, 2005. 3(10): p. 552-554.

229. Razzaghi-Abyaneh, M., M. ShamsGhahfarokhi, M.-B. Rezaee, K. Jaimand, S. Alinezhad, R. Saberi, et al., Chemical composition and antiaflatoxigenic activity of Carum carvi L., Thymus vulgaris and Citrus 
aurantifolia essential oils. Food Control, 2009. 20(11): p. 1018-1024.

230. Okigbo, R. and A. Ajalie, Inhibition of some human pathogens with tropical plant extractsChromolaena odorata and Citrus aurantifolia, and some antibiotics. International Journal of Molecular Medicine and Advance Sciences, 2005. 1(1): p. 34-40.

231. Sandoval-Montemayor, N.E., A. García, E. Elizondo-Treviño, E. Garza-González, L. Alvarez, and M. del Rayo Camacho-Corona, Chemical composition of hexane extract of Citrus aurantifolia and anti-Mycobacterium tuberculosis activity of some of its constituents. Molecules, 2012. 17(9): p. 11173-11184.

232. Wu, Y., C. Zeng, and Y. Gong, Study on antimicrobial effect of Bambusa vulgaris cv. Vittata leaf extracts. Food Sci Technol, 2008. 1: p. 194-196.

233. Rajeshwari, E., Evaluation of anti-microbial activity of Bambusa vulgaris leaves. International Journal of Phytotherapy Research, 2012. 2(2): p. 36-39.

234. Yakubu, M.T. and B.B. Bukoye, Abortifacient potentials of the aqueous extract of Bambusa vulgaris leaves in pregnant Dutch rabbits. Contraception, 2009. 80(3): p. 308-313.

235. Carey, W.M., J.M.B. Dasi, N.V. Rao, and K.M. Gottumukkala, Anti-inflammatory activity of methanolic extract of Bambusa vulgaris leaves. International Journal of Green Pharmacy (IJGP), 2009. 3(3).

236. Senthilkumar, M., P. Sivakumar, F. Changanakkattil, V. Rajesh, and P. Perumal, Evaluation of anti-diabetic activity of Bambusa vulgaris leaves in streptozotocin induced diabetic rats. Int J Pharm Sci Drug Res2011, 2011. 3: p. 208-10.

237. Ojo, O., J. Oluyege, and O. Famurewa, Antiviral properties of two Nigerian plants. African Journal of Plant Science, 2009. 3(7): p. 157-159.

238. Ogu, G.I., In Vitro Anthelmintic Potentials of Bambusa vulgaris (L.) Leaf Extracts Using Adult African Earthworm (Eudrilus eugeniae) from Southern Nigeria.

239. Alkiewicz, J. and B. Dabrowski, INVESTIGATIONS OF APPLICATION OF A LIOPHILIZED EXTRACT FROM GARLIC (ALLIUM-SATIVUM L) IN AEROSOLOTHERAPY OF RESPIRATORYTRACT DISEASES IN CHILDREN. Herba Polonica, 1982. 28(3-4): p. 195-204.

240. Chandra, H., A. Singh, J. Srivastava, P. Bishnoi, and A. Nautiyal, Antibacterial Activity of Allium sativum (L.) Against Bacteria Isolated from Upper Respiratory Tract. IUP Journal of Life Sciences, 2010. 4(4).

241. Polanco-Rojas, A.D. and A.N. Burgos-Arias, Qualitative study of the effect on consumption of the mother tincture of Allium sativum (garlic) in the lysozyme concentration and total protein in children under 6 years old with acute respiratory infection in the Hualqui Medic's office, VIII Region of Chile. BOLETIN LATINOAMERICANO $Y$ DEL CARIBE DE PLANTAS MEDICINALES Y AROMATICAS, 2013. 12(3): p. 294-301.

242. Kumar, P., D. Kumar, and A. Srivastava, Investigating Potential of Garlic (Allium Sativum) on Cardio-Respiratory Parameters and Lipid Profile of Smokers in Moradabad Region Uttar Pradesh.

243. Iwueke, A., O. Nwodo, and C. Okoli, Evaluation of the anti-inflammatory and analgesic activities of Vitex doniana leaves. African Journal of Biotechnology, 2006. 5(20): p. 1929.

244. Ladeji, O., S. Zebulon, and F.U. Okoye, Effects of Vitex doniana stem bark on blood pressure. Nigerian journal of natural products and medicine, 1997. 1(1): p. 19-20.

245. Higham, J.P., C. Ross, Y. Warren, M. Heistermann, and A.M. MacLarnon, Reduced reproductive function in wild baboons (Papio hamadryas anubis) related to natural consumption of the African black plum (Vitex doniana). Hormones and Behavior, 2007. 52(3): p. 384-390.

246. Ladeji, O. and Z.S. Okoye, Anti-hepatotoxic properties of Vitex doniana bark extract. International journal of pharmacognosy, 1996. 34(5): p. 355-358.

247. Suleiman, M. and S. Yusuf, Antidiarrheal Activity of the Fruits of Vitex doniana. in Laboratory Animals. Pharmaceutical Biology, 2008. 46(6): p. 387-392.

248. Oche, O., I. Sani, N.G. Chiaka, N.U. Samuel, and A. Samuel, Pancreatic islet regeneration and some liver biochemical parameters of leaf extracts of Vitex doniana in normal and streptozotocin-induced diabetic albino rats. Asian Pacific journal of tropical biomedicine, 2014. 4(2): p. 124-130.

249. Abdulrahman, F., P. Onyeyili, U. Sandabe, and V. Ogugbuaja, Evaluation of the effects of the aqueous extract of Vitex doniana root-bark on the peripheral and central nervous system of laboratory animals. Journal of Applied Sciences, 2007. 7(10): p. 1397-1403.

250. Ngouela, S., B.N. Lenta, D.T. Noungoue, J. Ngoupayo, F.F. Boyom, E. Tsamo, et al., Antiplasmodial and antioxidant activities of constituents of the seed shells of Symphonia globulifera Linn f. Phytochemistry, 2006. 67(3): p. 302-306.

251. Ngouela, S., B.L. Ndjakou, D.N. Tchamo, F. Zelefack, E. Tsamo, and J.D. Connolly, $A$ prenylated xanthone with antimicrobial activity from the seeds of Symphonia globulifera. Natural product research, 2005. 19(1): p. 2327.

252. Lenta, B.N., C. Vonthron-Sénécheau, R.F. Soh, F. Tantangmo, S. Ngouela, M. Kaiser, et al., In vitro antiprotozoal activities and cytotoxicity of some selected Cameroonian 
medicinal plants. Journal of ethnopharmacology, 2007. 111(1): p. 8-12.

253. Pan, E., S. Cao, P.J. Brodie, J.S. Miller, R. Rakotodrajaona, F. Ratovoson, et al., An antiproliferative xanthone of Symphonia pauciflora from the Madagascar rainforest. Natural product communications, 2010. 5(5): p. 751.

254. Oladosu, I., J. Echeme, and M. Zubair, Anticholinesterase and antibacterial activities of dioclimidazole from Dioclea reflexa seeds. Fitoterapia, 2006. 77: p. 571-75.

255. Iliemene, U.D. and S.E.-O. Atawodi, In vivo antioxidant and hepatoprotective effects of methanolic extract of dioclea reflexa seed in rats following acute or chronic liver injury. Bangladesh Journal of Pharmacology, 2014. 9(1): p. 112-117.

256. Edewor, T., O. Akpor, and S. Owa, Quantification of the total phenolic and flavonoid contents, and antibacterial activity of Dioclea reflexa. Int. J. PharmTech Res, 2014. 6: p. 1875-1880.

257. Emudainohwo, J., E. Erhirhie, E. Moke, and D. Ejebe, Hypoglycemic Effect of Ethanol Leaf Extract of Thuamatococus daneilli (ELETD) In Alloxan Induced Diabetic Wistar Rats. IOSR Journal of Pharmacy and Biological Sciences, 2015. 10(2): p. 59-64.

258. Adebayo, G.J. and L.A. Kolawole, In vitro activity of Thaumatococcus daniellii and Megaphrynium macrostachyum against spoilage fungi of white bread and 'Eba', an indigenous staple food in Southern Nigeria. African Journal of Microbiology Research, 2010. 4(11): p. 1076-1081.

259. Oboh, G., A.J. Akinyemi, I.S. Oyeleye, and K. Williamsnelson, Protective effect of phenolic extracts from two species of miracle berry leaves (Thaumatococcus daniellii and Megaphrynium macrostachyum) on some prooxidant induced oxidative stress in rat pancreas in vitro. Journal of Applied Pharmaceutical Science Vol, 2016. 6(01): p. 118-124.

260. Ojekale, A., S. Makinde, and O. Osileye, Phytochemistry and anti-microbial evaluation of Thaumatococcus danielli, Benn.(Benth.) leaves. Nigerian Food Journal, 2007. 25(2): p. 176-183.

261. Ojekale, A.B., O.A. Lawal, A.A. Segun, F.O. Samuel, A.I. Ismaila, and A.R. Opoku, Volatile Constituents, Antioxidant and Insecticidal Activities of Essential Oil from the Leaves of Thaumatococcus Danielli (Benn.) Benth. From Nigeria. losr Journal Of Pharmacy, 2013. 3(3): p. 01-05.

262. Segun, A.A., F.O. Samuel, and A.T. Aminat, Assessment of Antibacterial Activity of Essential Oil Extracted from Leaves of Thaumatococcus danielli (Benn.) Benth. in Light of its Inhibitory Impact on Extracellular Protease of Shigella dysenteriae. International
Journal of Biochemistry Research \& Review, 2015. 5(1): p. 9.

263. Minari, J.B., S. Ranjan, D. Kumar, P. Prasad, A.M. Hiremath, and S.R. Asolekar, AntiJaundice Properties of Methanolic Extract of Carica Papaya Leaves on Jaundice-Induced Albino Rat.

264. Boum, B., J. Pousset, F. Lemonnier, and M. Hadchouel, [Effect of Carica papaya extracts on experimental jaundice induced by the administration of Brenanis brieyi saponosides]. Toxicology and applied pharmacology, 1978. 46(2): p. 353-362.

265. Doughari, J., A. Elmahmood, and S. Manzara, Studies on the antibacterial activity of root extracts of Carica papaya L. Afr J Microbiol Res, 2007. 1(3): p. 37-41.

266. Ahmad, N., H. Fazal, M. Ayaz, B.H. Abbasi, I. Mohammad, and L. Fazal, Dengue fever treatment with Carica papaya leaves extracts. Asian Pacific journal of tropical biomedicine, 2011. 1(4): p. 330-333.

267. Okeniyi, J.A., T.A. Ogunlesi, O.A. Oyelami, and L.A. Adeyemi, Effectiveness of dried Carica papaya seeds against human intestinal parasitosis: a pilot study. Journal of medicinal food, 2007. 10(1): p. 194-196.

268. Oderinde, O., C. Noronha, A. Oremosu, T. Kusemiju, and O. Okanlawon, Abortifacient properties of aqueous extract of Carica papaya (Linn) seeds on female SpragueDawley rats. The Nigerian postgraduate medical journal, 2002. 9(2): p. 95-98.

269. Owoyele, B.V., O.M. Adebukola, A.A. Funmilayo, and A.O. Soladoye, Antiinflammatory activities of ethanolic extract of Carica papaya leaves. Inflammopharmacology, 2008. 16(4): p. 168173.

270. Olagunju, J., A. Adeneye, B. Fagbohunka, N. Bisuga, A. Ketiku, A. Benebo, et al., Nephroprotective activities of the aqueous seed extract of Carica papaya Linn. in carbon tetrachloride induced renal injured Wistar rats: a dose-and time-dependent study. Biol Med, 2009. 1(1): p. 11-9.

271. Oduola, T., F. Adeniyi, E. Ogunyemi, I. Bello, and T. Idowu, Antisickling agent in an extract of unripe pawpaw (Carica papaya): Is it real? African Journal of Biotechnology, 2006. 5(20).

272. Colker, C.M., D.S. Kaiman, G.C. Torina, T. Perlis, and C. Street, Effects of Citrus aurantium extract, caffeine, and St. John's wort on body fat loss, lipid levels, and mood states in overweight healthy adults. Current Therapeutic Research, 1999. 60(3): p. 145153.

273. Asnaashari, S., A. Delazar, B. Habibi, R. Vasfi, L. Nahar, S. Hamedeyazdan, et al., Essential Oil from Citrus aurantifolia prevents ketotifen-induced weight-gain in mice. Phytotherapy Research, 2010. 24(12): p. 1893-1897. 
274. Kim, G.-S., H.J. Park, J.-H. Woo, M.-K. Kim, P.-O. Koh, W. Min, et al., Citrus aurantium flavonoids inhibit adipogenesis through the Akt signaling pathway in 3T3-L1 cells. BMC complementary and alternative medicine, 2012. 12(1): p. 31.

275. Dallas, C., A. Gerbi, G. Tenca, F. Juchaux, and F.-X. Bernard, Lipolytic effect of a polyphenolic citrus dry extract of red orange, grapefruit, orange (SINETROL) in human body fat adipocytes. Mechanism of action by inhibition of cAMP-phosphodiesterase (PDE). Phytomedicine, 2008. 15(10): p. 783-792.

276. Loizzo, M.R., R. Tundis, M. Bonesi, F. Menichini, D. De Luca, C. Colica, et al., Evaluation of Citrus aurantifolia peel and leaves extracts for their chemical composition, antioxidant and anti-cholinesterase activities. Journal of the Science of Food and Agriculture, 2012. 92(15): p. 2960-2967.

277. Vinha, A.F., S.V. Barreira, A.S. Costa, R.C. Alves, and M.B.P. Oliveira, Pre-meal tomato (Lycopersicon esculentum) intake can have anti-obesity effects in young women? International journal of food sciences and nutrition, 2014. 65(8): p. 1019-1026.

278. Sasidharan, S., R. Nilawatyi, R. Xavier, L.Y. Latha, and R. Amala, Wound healing potential of Elaeis guineensis Jacq leaves in an infected albino rat model. Molecules, 2010. 15(5): p. 3186-3199.

279. Chong, K., Z. Zuraini, S. Sasidharan, P. Kalnisha Devi, L. Yoga Latha, and S. Ramanathan, Antimicrobial activity of Elaeis guineensis leaf. Pharmacologyonline, 2008. 3: p. 379-386.

280. Yin, N., S. Abdullah, and C.K. Phin, Phytochemical constituents from leaves of Elaeis guineensis and their antioxidant and antimicrobial activities. Int $\mathrm{J}$ Pharm Pharmaceut Sci, 2013. 5: p. 137-140.

281. Manusia, T.B.P., PHYTOCHEMICAL SCREENING AND IN VITRO ANTIBACTERIAL ACTIVITY OF Elaeis guineensis LEAVES EXTRACTS AGAINST HUMAN PATHOGENIC BACTERIA. Malaysian Journal of Analytical Sciences, 2015. 19(4): p. 775-780.

282. Aibinu, T.A.I., Evaluation of the antimicrobial properties of different parts of Citrus aurantifolia (lime fruit) as used locally. 2007.

283. Ezeonu, F., G. Chidume, and S. Udedi, Insecticidal properties of volatile extracts of orange peels. Bioresource technology, 2001. 76(3): p. 273-274.

284. Shalaby, N.M., H.I. Abd-Alla, H.H. Ahmed, and N. Basoudan, Protective effect of Citrus sinensis and Citrus aurantifolia against osteoporosis and their phytochemical constituents. J Med Plants Res, 2011. 5(4): p. 579-588.

285. Allouh, M.Z., H.M. Daradka, M.M. Al Barbarawi, and A.G. Mustafa, Fresh onion juice enhanced copulatory behavior in male rats with and without paroxetine-induced sexual dysfunction. Experimental Biology and Medicine, 2014. 239(2): p. 177-182.

286. Morris, J. and M. Wang. Anthocyanin and potential therapeutic traits in Clitoria, Desmodium, Corchorus, Catharanthus and Hibiscus species. in International Symposium on Medicinal and Nutraceutical Plants 756. 2007.

287. Adedosu, O.T., O.E. Akanni, O.K. Afolabi, and A.L. Adedeji, Effects of Corchorus olitorius Extract on Certain Antioxidants and Biochemical Indices in Sodium Arsenite Exposed Rats. American Journal of Phytomedicine and Clinical Therapeutics, 2015. 3(3): p. 245-256.

288. Vasudeva, N., S.K. Sharma, and A. Mor, Spermicidal and Post-Coital Anti-Fertility Activity of Vitex Negundo Stem Bark. Journal of herbs, spices \& medicinal plants, 2012. 18(4): p. 287-303.

289. Pal, D., M. Mandal, G. Senthilkumar, and A. Padhiari, Antibacterial activity of Cuscuta reflexa stem and Corchorus olitorius seed. Fitoterapia, 2006. 77(7): p. 589-591.

290. Oboh, G., A.O. Ademiluyi, A.J. Akinyemi, T. Henle, J.A. Saliu, and U. Schwarzenbolz, Inhibitory effect of polyphenol-rich extracts of jute leaf (Corchorus olitorius) on key enzyme linked to type 2 diabetes ( $\alpha$-amylase and $\alpha$ glucosidase) and hypertension (angiotensin I converting) in vitro. Journal of Functional Foods, 2012. 4(2): p. 450-458.

291. Zeid, A.H.S.A., Stress metabolites from Corchorus olitorius $L$. leaves in response to certain stress agents. Food Chemistry, 2002. 76(2): p. 187-195.

292. Gupta, M., U. Mazumder, D. Pal, and S. Bhattacharya, Anti-steroidogenic activity of methanolic extract of Cuscuta reflexa roxb. stem and Corchorus olitorius Linn. seed in mouse ovary. Indian journal of experimental biology, 2003. 41(6): p. 641-644.

293. Yan, Y.-Y., Y.-W. Wang, S.-L. Chen, S.-R. Zhuang, and C.-K. Wang, Anti-inflammatory effects of phenolic crude extracts from five fractions of Corchorus Olitorius L. Food chemistry, 2013. 138(2): p. 1008-1014.

294. Vohora, S., M. Shamsi, and M. Khan, Antipyretic and analgesic studies on the diacetate of a new triterpenic acid isolated from Corchorus depressus $L$. Journal of ethnopharmacology, 1981. 4(2): p. 223-228.

295. Adegoke, S.A., U.A. Shehu, L.O. Mohammed, Y. Sanusi, and O.A. Oyelami, Influence of lime juice on the severity of sickle cell anemia. The Journal of Alternative and Complementary Medicine, 2013. 19(6): p. 588-592.

296. Afolabi, I., P. Daniels, S. Rotimi, and A. Adeyemi, An Evaluation of Lipid Profile and Antioxidant Activities of Carica Papaya Seed Oil in the Heart and Liver of Female Wistar Rats. Nigerian Journal of Natural Products and Medicine, 2014. 16(1): p. 11-17. 
297. Kumar, A., M. Pant, H. Pandey, J. Aggarwal, R. Sharma, L. Joshi, et al., Effect of feeding Carica papaya (Papita) fruits on blood lipid profile of albino rabbits. Indian Journal of Clinical Biochemistry, 1993. 8(1): p. 47-50.

298. Rahmat, A., M. Abu Bakar, N. Faezah, and Z. Hambali, The effects of consumption of guava (psidium guajava) or papaya (carica papaya) on total antioxidant and lipid profile in normal male youth. Asia Pacific Journal of Clinical Nutrition, 2004. 13.

299. Chau, C.-F., Y.-L. Huang, and C.-Y. Lin, Investigation of the cholesterol-lowering action of insoluble fibre derived from the peel of Citrus sinensis L. CV. Liucheng. Food Chemistry, 2004. 87(3): p. 361-366.

300. Parmar, H.S. and A. Kar, Protective role of Citrus sinensis, Musa paradisiaca, and Punica granatum peels against diet-induced atherosclerosis and thyroid dysfunctions in rats. Nutrition Research, 2007. 27(11): p. 710718.

301. Trovato, A., M. Monforte, R. Barbera, A. Rossitto, E. Galati, and A. Forestieri, Effects of fruit juices of Citrus sinensis $L$. and Citrus limon L. on experimental hypercholesterolemia in the rat. Phytomedicine, 1996. 2(3): p. 221227.

302. Gorinstein, S., H. Leontowicz, M. Leontowicz, R. Krzeminski, M. Gralak, O. Martin-Belloso, et al., Fresh Israeli Jaffa blond (Shamouti) orange and Israeli Jaffa red Star Ruby (Sunrise) grapefruit juices affect plasma lipid metabolism and antioxidant capacity in rats fed added cholesterol. Journal of agricultural and food chemistry, 2004. 52(15): p. 48534859.

303. Oluremi, O., J. Ngi, and I. Andrew, Phytonutrients in citrus fruit peel meal and nutritional implication for livestock production. Livestock research for rural development, 2007. 19(7): p. 345-346.

304. Oben, J., E. Enonchong, S. Kothari, W. Chambliss, R. Garrison, and D. Dolnick, Phellodendron and Citrus extracts benefit cardiovascular health in osteoarthritis patients: a double-blind, placebo-controlled pilot study. Nutrition journal, 2008. 7(1): p. 1.

305. Vinson, J.A., X. Liang, J. Proch, B.A. Hontz, J. Dancel, and N. Sandone, Polyphenol antioxidants in citrus juices: in vitro and in vivo studies relevant to heart disease, in Flavonoids in Cell Function. 2002, Springer. p. 113-122.

306. Oben, J., E. Enonchong, S. Kothari, W. Chambliss, R. Garrison, and D. Dolnick, Phellodendron and Citrus extracts benefit joint health in osteoarthritis patients: a pilot, doubleblind, placebo-controlled study. Nutrition journal, 2009. 8(1): p. 1.

307. Anagnostopoulou, M.A., P. Kefalas, V.P. Papageorgiou, A.N. Assimopoulou, and D. Boskou, Radical scavenging activity of various extracts and fractions of sweet orange peel
(Citrus sinensis). Food chemistry, 2006. 94(1): p. $19-25$.

308. Fabricant, D.S. and N.R. Farnsworth, The value of plants used in traditional medicine for drug discovery. Environmental health perspectives, 2001. 109(Suppl 1): p. 69.

309. Ogle, B.M., H.T. Tuyet, H.N. Duyet, and N.N. Xuan Dung, Food, feed or medicine: the multiple functions of edible wild plants in Vietnam. Economic Botany, 2003. 57(1): p. 103-117.

310. Wang, L. and C.L. Weller, Recent advances in extraction of nutraceuticals from plants. Trends in Food Science \& Technology, 2006. 17(6): p. 300-312.

311. Abo, K., A. Adeyemi, and D. Adeite, Ethnobotanical survey of plants used in the treatment of infertility and sexually transmitted diseases in southwest Nigeria. African journal of medicine and medical sciences, 2000. 29(34): p. 325-327.

312. Sofidiya, M., O. Odukoya, A. Afolayan, and O. Familoni, Survey of anti-inflammatory plants sold on herb markets in Lagos Nigeria. International Journal of Botany, 2007.

313. Sharaibi, O.J., O.T. Ogundipe, A.J. Afolayan, and D.O. Aworinde, Ethnobotanical survey and phytochemical analysis of medicinal plants used for the treatment of hyperprolactinemia in Lagos State, Nigeria. Journal of Medicinal Plants Research, 2014. 8(43): p. 1284-1288.

314. Oshikoya, K.A., I.O. Senbanjo, O.F. Njokanma, and A. Soipe, Use of complementary and alternative medicines for children with chronic health conditions in Lagos, Nigeria. BMC Complementary and Alternative Medicine, 2008. 8(1): p. 66.

315. Nwaiwu, O. and O. Oyelade, Traditional herbal medicines used in neonates and infants less than six months old in Lagos Nigeria. Nigerian Journal of Paediatrics, 2016. 43(1): p. 